\title{
Does Prospect Theory Explain IPO Market Behavior? *广
}

\author{
Alexander P. Ljungqvist \\ Salomon Center \\ Stern School of Business \\ New York University \\ and $C E P R$
}

\author{
William J. Wilhelm, Jr. \\ McIntire School of Commerce \\ University of Virginia \\ and Sä̈d Business School \\ University of Oxford
}

February 24, 2004

\footnotetext{
* Thanks for helpful comments go to Mike Cliff, Robert Daines, David Denis, Espen Eckbo, Miguel Ferreira, David Hirshleifer, Laurie Krigman, Jay Ritter, Ben Ross, Robert Stambaugh, Jeff Wurgler, an anonymous associate editor, an anonymous referee, and seminar participants at the Colloquium on Behavioral Finance at the NYU School of Law, the University of Oxford, Michigan State University, and Lisbon University. We gratefully acknowledge the contribution of Thomson Financial for providing broker recommendations data, available through the Institutional Brokers Estimate System. These data have been provided as part of a broad academic program to encourage earnings expectations research. All errors are our own.

${ }^{\dagger}$ Address for correspondence: Salomon Center, Stern School of Business, New York University, Suite 9-160, 44 West Fourth Street, New York NY 10012-1126. Phone 212-998-0304. Fax 212-995-4220. e-mail aljungqv@stern.nyu.edu.
} 


\title{
Does Prospect Theory Explain IPO Market Behavior?
}

\begin{abstract}
We derive a behavioral measure of the IPO decision-maker's satisfaction with the underwriter's performance based on Loughran and Ritter's (2002) application of prospect theory to IPO underpricing. We assess the plausibility of this measure by studying its power to explain the decision-maker's subsequent choices. Controlling for other known factors, IPO firms are less likely to switch underwriters for their first seasoned equity offering when our behavioral measure indicates they were satisfied with the IPO underwriter's performance. Underwriters also appear to benefit from behavioral biases in the sense that they extract higher fees for subsequent transactions involving satisfied decision-makers. Although our tests suggest there is explanatory power in the behavioral model, they do not speak directly to whether deviations from expected utility maximization determine patterns in IPO initial returns.
\end{abstract}

Key words: Prospect theory; Behavioral finance; Initial public offerings; Underpricing.

JEL classification: $G 31, G 24, G 14$ 
The primary equity (or IPO) markets are subject to a variety of well-known idiosyncratic patterns, not least the tendency for IPOs to appear underpriced on the first day of trading. The profession has invested heavily in explanations for these patterns (see Ritter and Welch (2002) and Jenkinson and Ljungqvist (2001) for recent reviews). The vast majority of theoretical work in the area builds (at least implicitly) on the premise that market participants are rational and maximize expected utility subject to the burden of market frictions. Asymmetric information of one sort or another is the friction most widely examined and there is a substantial body of evidence suggesting that such frictions account for at least some of the cross-sectional and time variation in the idiosyncratic patterns.

And yet the question remains whether we can explain more than a small fraction of variation in the data. Recent events related to the 'dot-com bubble' of the late 1990s lend weight to this concern and lead some researchers to suggest that shifting the focus of the research agenda will lead to more progress at the margin. The behavioral perspective represents an alternative to the asymmetric information approach but it engenders considerable skepticism among some economists on both philosophical and methodological grounds. With regard to the latter, behavioral theories often provide sufficient structure for tightly controlled laboratory experiments ${ }^{1}$ but insufficient structure for simple econometric exercises that meaningfully control for the myriad forces at play in financial markets.

The lone published application of the behavioral paradigm to the IPO market is that of Loughran and Ritter (2002). Combining prospect theory with Thaler's $(1980,1985)$ notion of mental accounting, Loughran and Ritter argue that issuers fail to 'get upset' about leaving millions of dollars 'on the table' in the form of large first-day returns because they tend to sum the wealth loss due to underpricing with the (often larger) wealth gain on retained shares as prices jump in the after-market. Such 'complacent' behavior benefits the investment bank if investors engage in rent-seeking to increase their chances of being allocated underpriced stock.

\footnotetext{
${ }^{1}$ It is perhaps more accurate to say that the descriptive theory of choice associated most prominently with Kahneman and Tversky (1979) arose from such tightly controlled experiments.
} 
In this paper, we use the structure suggested by Loughran and Ritter's (2002) behavioral perspective to test whether the CEOs of recent IPO firms make subsequent decisions consistent with a behavioral measure of their perception of the IPO's outcome. Specifically, we form two variables proxying for whether, and to what degree, the CEO responsible for an IPO was 'satisfied' with the underwriter's performance given his wealth loss due to underpricing and his (perceived) wealth gain due to the revaluation of his retained shares relative to his anchor value. Loughran and Ritter assume the CEO anchors his valuation on the midpoint of the indicative price range filed with the S.E.C.

We then examine which bank the IPO firm chooses as underwriter for its first seasoned equity offering (SEO). Specifically, we test whether the CEO is more likely to retain the IPO underwriter to lead-manage the follow-on offer when the behavioral proxies indicate he was satisfied with the IPO outcome. From the perspective of expected utility theory, the behavioral proxies should of course have no explanatory power. Thus if IPO decision-makers reveal their preferences through their subsequent decisions, the plausibility of the underpinnings of Loughran and Ritter's (2002) behavioral story can be examined fairly directly.

We emphasize that this test can reject only the following joint hypothesis:

(1) IPO decision-makers anchor on the specific measure of firm value asserted by Loughran and Ritter (2002);

(2) the mapping from an unobserved value function of the form implied by prospect theory to a statement of the decision-maker's satisfaction with the IPO outcome takes the explicit form hypothesized by Loughran and Ritter;

(3) decision-maker satisfaction with the IPO outcome influences the decision whether to engage the same bank to underwrite the IPO issuer's first SEO. ${ }^{2}$

The test does not speak directly to whether behavioral deviations from expected utility maximization

\footnotetext{
${ }^{2}$ A strictly rational CEO should view past experience as sunk although perhaps informative of the bank's ability. Assuming the latter is true and given that our proxies for decision-maker satisfaction are derived from public information, such signals should be incorporated in the bank's reputation. Thus our tests control for the reputation of banks within the issuer's subsequent choice set.
} 
determine patterns in IPO initial returns but it does shed light on the plausibility of the underlying structure necessary for such a linkage to exist. An explicit characterization and test of this linkage remains a significant challenge for future research.

The issuer's choice of underwriter has recently received considerable scrutiny. Most pertinent to our analysis is the work of Krigman, Shaw, and Womack (2001) who claim "there is little evidence that firms switch [underwriters] due to dissatisfaction with underwriter performance at the time of the IPO”, noting that switchers suffered less IPO underpricing than non-switchers in their sample. Rather, they contend that firms 'graduate' to more prestigious underwriters whenever possible and strategically acquire additional and more influential analyst coverage through their choice of underwriters (also see Cliff and Denis (2003) on the latter point).

In contrast to Krigman, Shaw, and Womack (2001), we find that IPO firms are more likely to switch underwriters after the IPO when our behavioral proxies suggest that they were dissatisfied with the IPO underwriter's performance. This difference arises because we measure dissatisfaction along the lines of Loughran and Ritter (2002) rather than focusing on underpricing. The finding by Krigman, Shaw, and Womack of significantly less underpricing among firms switching underwriters does not persist when we include the behavioral proxies for decision-maker satisfaction.

The behavioral interpretation is more plausible when the issuer's CEO, with whom the choice of underwriter ultimately rests, is the same at both the IPO and the SEO. Consistent with the behavioral interpretation, the explanatory power of our proxies is concentrated among firms for which the CEO does not change between the two events. Moreover, controlling for CEO background, we find evidence suggesting that more experienced and skilled CEOs are less prone to behavioral biases.

The central result, that satisfaction with the IPO outcome diminishes the probability of switching underwriters at the first SEO, also holds when the behavioral proxies for decision-maker satisfaction are measured for the group of senior executives collectively. On the other hand, when we focus attention on venture-backed firms, we find no evidence that their switching behavior is influenced 
by behavioral proxies for the venture capitalists' satisfaction with the IPO outcome. Given their regular participation in the IPO process, VCs may be less inclined toward behavioral biases.

Alternatively, VCs may not be particularly influential in the selection of an underwriter after the IPO.

These results arise in qualitative choice models that control for a variety of forces previously documented in the literature. Specifically, less mature firms are more likely to switch underwriters at their first SEO, as are companies that were taken public by less prestigious underwriters, consistent with the 'graduation' effect. We also find evidence of 'strategic analyst coverage' in the sense that issuers are more likely to switch when their IPO underwriter did not provide research coverage for the issuer's stock.

Controlling for these other factors, it is noteworthy that decision-maker satisfaction does not reduce the likelihood of switching underwriters among issuers completing their first SEO after the bursting of the 'dot-com bubble' in the second quarter of 2000. One plausible interpretation of this result is that fallout from the 'dot-com bubble' bursting served as an 'eye-opener', substantially undermining any goodwill IPO underwriters built up at the IPO.

Finally, underwriters appear to benefit from behavioral biases in the sense that they extract higher fees for subsequent transactions involving satisfied decision-makers. Thus satisfaction with the IPO outcome is associated with both a reduced likelihood of switching underwriters after the IPO and paying higher fees for SEO underwriting services.

The paper proceeds as follows. Section I embeds our test of the behavioral model by Loughran and Ritter (2002) in the existing literature on IPO underpricing and issuing companies' choice of SEO underwriter. Section II describes our sample and data sources. In Section III, we estimate the link between issuing companies' switching decisions and our behavioral proxies. Section IV concludes.

\section{Theory and Hypotheses}

\section{A. A Behavioral Measure of Decision-Maker Satisfaction with Underwriter Performance}

A central tenet of behavioral choice theory holds that decisions are influenced by how choices 
are framed. Considerable evidence derived from controlled experiments supports this claim and suggests other systematic deviations from expected utility maximization. These findings provide the foundation for Kahneman and Tversky's (1979) formulation of prospect theory. ${ }^{3}$ Prospect theory asserts that individuals make choices under uncertainty by maximizing a value function that evaluates wealth changes, rather than an expected utility function that ranks choices according to the level of expected utility. The value function is positive and concave in the domain of positive changes (from the anchor level) and negative and convex in the domain of negative changes.

Loughran and Ritter (2002) assume that the decision-maker's initial valuation beliefs are reflected in the mean of the indicative price range reported in the issuing firm's IPO registration statement. This belief serves as a reference point against which the gain or loss from (as opposed to the expected utility of) the outcome of the IPO can be assessed. The offer price for an IPO routinely differs from this reference point, either because the bank 'manipulated' the decision-maker's expectations by lowballing the price range, or in reflection of information revealed during marketing efforts directed at institutional investors. Empirically, offer prices appear only to 'partially adjust' (Hanley (1993)) in the sense that large positive revisions from the reference point are associated with large initial price increases from the offer price during the first day of trading. Such partial adjustment is consistent with both the Benveniste and Spindt (1989) information-acquisition model of IPO underpricing and Loughran and Ritter's complacency argument.

Decision-makers in IPO firms are further assumed to distinguish between losses associated with "money left on the table" in the form of positive initial returns and the perceived gains (or losses) reflected in the difference between the first-day closing price and the mean of the indicative price range. Applied in the context of the prospect theory value function, this form of mental accounting (Thaler (1980, 1985)) leads to gains and losses being valued separately (segregated) or jointly (integrated) depending on which yields the highest net value. The convexity of the value function for

\footnotetext{
${ }^{3}$ See Shefrin and Statman (1984) for a discussion of prospect theory in a financial-markets context.
} 
negative wealth changes implies that decision makers will integrate two related losses. Concavity of the value function in the positive domain implies that two related gains will be segregated. Whether the combination of a loss and a gain will be integrated or segregated depends on their relative size.

The decision-making unit in this setting is the CEO of the issuing firm or a management group that might include other influential members such as a venture capitalist. It is safe to assume that the decision-maker has an equity stake in the firm, a varying fraction (in a cross-section of firms) of which is sold in the IPO. Thus the decision-maker perceives a positive revision from the reference point as a wealth gain (assuming he retains shares after the IPO). At the same time, a positive initial return is perceived as a wealth loss under the assumption that shares could have been sold at the higher first-day trading price. Loughran and Ritter (2002) argue that the decision-maker integrates gains and losses and thus judges the outcome of the IPO according to its net effect if

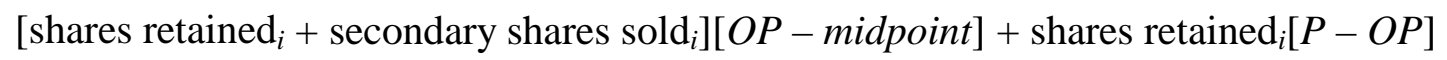

$>[P-O P]\left[\right.$ secondary shares sold ${ }_{i}+$ primary shares sold $\left(\right.$ shares retained $_{i} /$ shares retained $\left.)\right]$

where subscript $i$ indexes the decision-maker, secondary shares sold refers to the number of personal shares sold by the decision-maker in the IPO, OP is the offer price, midpoint is the mean of the indicative price range (the anchor value), $P$ is the closing price for the first day of trading, primary shares are newly issued stock sold in the IPO, and the unsubscripted value of shares retained represents total retention among all initial shareholders.

In words, expression (1) states that a perceived gain arising from a positive revision to the reference point and an actual loss associated with selling shares subject to a positive initial return will be integrated and thus viewed with positive net value if the decision-maker's share of the perceived underpricing loss is smaller than his perceived gain from the positive revision relative to the reference point. Loughran and Ritter (2002) use Netscape's 1995 IPO to illustrate expression (1). James Clark, Netscape's co-founder, saw the value of his 9.34 million shares increase from $\$ 121$ million, 
valued at the midpoint of the indicative price range, to $\$ 544$ million on the first day of trading. At the same time, \$43 million of the \$151 million 'left on the table' in the form of underpriced stock came out of his pocket. According to expression (1) the good news more than made up for the bad news and so the two outcomes would be integrated. Accordingly, this should have left Mr. Clark satisfied with the overall outcome of the IPO, rather than disappointed with the underwriter for leaving \$43 million of his money on the table.

Expression (1) suggests a crude proxy for the IPO decision-maker's satisfaction with the performance of the issuing firm's investment banker. Assuming price revisions and initial returns are perceived as Loughran and Ritter (2002) conjecture and that the decision-maker mentally integrates gains and losses consistent with a value function of the form described above, expression (1) yields both a binary indicator of whether the decision-maker was satisfied with the bank's performance and a dollar-valued measure of the degree of satisfaction (or dissatisfaction). The binary indicator equals one if condition (1) is true - that is, if the perceived gain arising from the positive revision to the reference point exceeds the actual underpricing loss - and zero otherwise. The dollar-valued measure computes the net perceived gain, that is, the left-hand side of condition (1) less the right-hand side.

The test we propose establishes a null hypothesis of a direct relation between the IPO decisionmaker's probability of choosing the IPO underwriter to manage subsequent securities market transactions and the decision-maker's satisfaction with the bank's performance in the IPO. The explicit structure for the behavioral proxies implied by (1) is not consistent with expected utility maximization, for it assumes decision-makers put weight on something that is meaningless in a rational framework: the perceived change in wealth relative to the reference point. Thus with sufficient control over the alternative potential influences on subsequent decisions (reviewed in the following subsection), the specific characterization of prospect theory implied by (1) is refutable.

\section{B. Related Work}

A substantial body of theory suggests that, other things equal, firms develop relationships with 
financial intermediaries as a means of preserving strategic advantage in product markets and conserving resources devoted to information production when issuers are privately informed about their quality (see Petersen and Rajan (1994, 1995), Boot and Thakor (2000), Anand and Galetovic (2000)). Despite such considerations, firms frequently do not retain their IPO underwriter for subsequent capital market transactions. However, the most widely cited empirical analysis of firms that switch underwriters at their first SEO (Krigman, Shaw, and Womack (2001)) suggests that the switching decision is not driven by dissatisfaction with underwriter performance during the IPO. Switchers actually suffer less IPO underpricing than non-switchers in their sample.

Existing theories of IPO underpricing driven by informational frictions do not obviously predict an inverse relation between underpricing and satisfaction with the underwriting bank's performance. From Rock's (1986) perspective, the underwriter is not accountable for the structural failure in the primary market that gives rise to underpricing. Research stemming from Benveniste and Spindt (1989) suggests that banks should be held accountable for the degree of underpricing but only conditional on, at least, the state of the market's information structure and the bargaining power of investor constituencies. Biais, Bossaerts, and Rochet (2002) admit potential for conflicts of interest between the issuer and underwriter (Baron (1982)) and reach a conclusion open to similar interpretation. Among the empirical studies in this area, the work of Nanda and Yun (1997) is noteworthy for the finding that overpricing (negative initial returns) is costly to underwriters in the sense that their own stock market valuations decline.

Other determinants of the decision to switch underwriters can be organized into three groups. Krigman, Shaw, and Womack (2001) suggest that issuers seek to 'graduate' to more reputable underwriters. In a related vein, Carter (1992) investigates why firms raise equity following their IPO and finds that, conditional on reissuing, the likelihood of switching underwriters decreases in the IPO underwriter's reputation. A second determinant of the switching decision suggested by previous work reflects the issuer's interest in having its stock covered by a reputable research analyst. Krigman, 
Shaw, and Womack provide both statistical and survey evidence on this point. Cliff and Denis (2003) investigate whether issuers indirectly compensate the underwriter for research coverage by tolerating greater underpricing. Finally, Fernando, Gatchev, and Spindt (2003) argue that underwriters and issuers engage in 'positive assortive matching' whereby counter-parties mutually seek partners of similar quality or repute. For our purposes, the primary point of interest is the implication that issuers experiencing a decline in quality between their IPO and first SEO are more likely to switch.

\section{Sample and Data}

\section{A. The IPO Sample}

The sample consists of all firms completing an initial public offering in the U.S. between January 1993 and December 2000. Closing the sample period at year-end 2000 provides at least 33 months for any sample firm to return to the market using September 30, 2003 as the latest date for identifying a subsequent equity offering. Thomson Financial's SDC database lists 3,435 completed IPOs during 1993-2000, after excluding unit offers, closed-end funds and REITs, ADRs of companies already listed in their home countries, limited partnerships, penny stocks (IPOs with offer prices below \$5), and financial firms (SIC codes 60-69).

As condition (1) makes clear, the behavioral proxies for issuer satisfaction require data on pre-IPO ownership and at-IPO sales, which we collect from IPO prospectuses. After May 1996, most prospectuses are available on the S.E.C.'s EDGAR service. Missing prospectuses, and those filed before May 1996, are obtained from Disclosure's Global Access system (now called Thomson Research). We lack prospectuses for nine of the 3,435 sample IPOs.

Closing prices for the first day of trading are obtained from the CRSP database. For the 49 sample firms not covered in CRSP within three days of their offer dates, first-day closing prices reported by SDC are checked against the share price database provided at nasdaq.com. Gaps in SDC coverage of company founding dates are filled with information from the issuer's prospectus. Firms identified by SDC as 0-3 years old at the IPO are cross-checked since SDC frequently reports the most recent 
incorporation date rather than the date when operations commenced. ${ }^{4}$

\section{B. Identifying Seasoned Equity Offers}

Our test focuses strictly on decisions related to the issuer's first post-IPO equity offering under the assumption that the residual influence of the IPO experience decays rapidly with subsequent equity offerings. ${ }^{5}$ Matching IPO and SEO firms is a non-trivial task as a consequence of frequent name and CUSIP changes. SDC assigns a unique company identification code to each issuer which generally remains constant when the firm's name or CUSIP changes. The SDC code identifies 1,093 first-time SEOs completed before September 30, 2003 by firms in the 1993-2000 IPO cohort. I.R.S. tax numbers provide a second, generally stable, identification code. This approach yields an additional 75 SEOs for our IPO cohort. Finally, we perform a name match by hand and identify a further 35 firsttime SEOs in cases where both the SDC and I.R.S. identification codes changed. In sum, 1,203 of the 3,435 firms in our IPO cohort completed a first SEO between 1993 and September 30, $2003{ }^{6}$

The more time elapses between the IPO and the SEO, the less likely it is that an issuer's choice of SEO underwriter is influenced by events at the time of the IPO. The median SEO occurred 391 calendar days after the IPO. The distribution is right-skewed with a mean of 588 days. Among those returning to the equity market, 167 IPO firms (13.9\%) did so more than three years after their IPO. Following Cliff and Denis (2003) (but in contrast to Krigman, Shaw, and Womack (2001)) these 'late' SEOs are retained in the sample and the time-to-SEO is controlled directly in the empirical analysis.

Excluding late SEO issuers from the sample yields virtually identical results.

Table I provides summary statistics for the entire sample of IPO firms and for those that

\footnotetext{
${ }^{4}$ For IPOs of corporate divisions, we attempted to determine the date when the division commenced operations. This date normally preceded the date of the division's incorporation. In roll-ups and similar acquisition-based IPOs, the issuer's founding date is the earliest founding date of any of its constituent firms.

${ }^{5}$ Excluding subsequent debt offerings avoids confounding switching decisions that arise not from dissatisfaction with the IPO underwriting effort but from differences in debt and equity capabilities within banks. On the other hand, this approach leaves open the possibility of switches that reflect a relationship nurtured over the course of multiple intervening debt offerings rather than dissatisfaction with the IPO underwriter. However, only 54 sample companies issue bonds between their IPO and their first SEO, and controlling explicitly for these intervening debt offerings leaves our results unchanged. ${ }^{6}$ Cliff and Dennis (2003) identify 1,050 SEOs completed by December 31, 2001 for the same cohort of IPOs completed in 1993-2000. Over their time period, we identify an additional 89 first-time SEOs as a result of matching on I.R.S. tax numbers and company names.
} 
subsequently raise equity and those that do not. The decision to raise additional equity is not random. If it is driven by factors that also affect the choice of underwriter, selection bias can arise. Table I reports tests of differences in characteristics across the two sub-samples to establish whether a formal Heckman correction for selection bias is called for.

The first block of summary statistics indicates that the reissuing firms had greater intended (filing) and actual offer proceeds and were older at the time of the IPO, consistent with prior findings in the literature. More importantly for our purposes, the two sub-groups do not differ in terms of the firstday return or the offer price revision from the mean of the indicative price range reported in the issuer's registration statement. The second block of summary statistics shows that follow-on issuers were significantly more profitable and larger at the time of their IPO (measured by either pre-IPO revenue or book value of assets). The third block suggests that follow-on issuers engaged more prestigious IPO underwriters (based on Jay Ritter's update to the Carter-Manaster (1990) underwriter 'tombstone' rankings). Finally, the fourth block of summary statistics reveals few significant differences in ownership structure, except that follow-on issuers had somewhat lower CEO ownership, were more often venture-backed at their IPO, and more frequently saw their insiders ${ }^{7}$ and venture backers sell stock in the IPO.

In sum, companies completing follow-on equity offers raised more money at the IPO, were larger and more profitable, used more prestigious IPO underwriters, and were more often venture-backed. Importantly, there are few significant differences among the key elements of the behavioral proxy for issuer satisfaction - ownership, retention, price revisions relative to the filing range, and initial returns - suggesting that selection bias is not a serious problem in the data. ${ }^{8}$

\footnotetext{
${ }^{7}$ Prospectuses report the aggregate stake held by all directors and executive officers as a group, whom we refer to collectively as insiders.

${ }^{8}$ Our main findings are robust to formally modeling the decision to raise follow-on equity using the probit version of Heckman's (1979) two-step model, where the decision to reissue is modeled as a function of the intended size of the IPO, a dummy variable identifying firms in 'nascent' industries (see Benveniste, Ljungqvist, Wilhelm, and Yu (2003) for how this is coded), and year effects. Firms raising larger amounts at the IPO and those in nascent industries are likely to have larger capital needs, and so are more likely to reissue, which is indeed the case. However, a likelihood ratio test cannot reject the null that the decisions to reissue and to switch underwriters are independent at the $5 \%$ level of significance.
} 


\section{Coding Switches}

The sample period witnessed numerous mergers among investment banks and acquisitions of investment banks by commercial banks. Against this background, firms are identified as switching banks when the IPO lead manager, or relevant successor entity, is not chosen to lead-manage the first SEO. Successor entities are identified using the information in Corwin and Schultz (2003) and Ljungqvist, Marston, and Wilhelm (2003). For instance, a firm taken public by Dean Witter that subsequently hired Morgan Stanley Dean Witter as SEO underwriter is classified as a non-switcher. The 22 firms with multiple lead-managers at the IPO are classified as switchers only when they do not rehire at least one of their IPO managers. Using this classification scheme, 432 (35.9\%) of the 1,203 IPO firms carrying out their first SEO by September 30, 2003 switched underwriters. Cliff and Denis (2003) report a 33.5\% switching rate for the same IPO cohort (though over a shorter window) and Krigman, Shaw, and Womack (2001) report a 30\% switching rate for an IPO cohort from 1993-1995.

\section{The Behavioral Measure of Satisfaction with IPO Underwriter Performance}

We use condition (1) to code both a binary and a dollar-valued behavioral proxy for issuer satisfaction. The binary version equals one if condition (1) is true - that is, if the perceived gain arising from the positive offer price revision exceeds the actual loss due to underpricing - and zero otherwise. The dollar-valued version computes the perceived gain net of the underpricing loss.

Table II provides summary statistics for the behavioral proxies. From the perspective of the CEO as the decision-maker, $58.9 \%$ of the SEO issuers are classified as having been satisfied with the performance of their IPO underwriter. Among those switching underwriters, only $48.8 \%$ are classified as satisfied while for those that continued their relationship with their IPO underwriter $64.5 \%$ are classified as satisfied with the underwriter's performance in the IPO. The dollar-valued version of the proxy tells a similar story. The mean (median) non-switching CEO enjoyed a perceived wealth gain of $\$ 21.5 \mathrm{~m}(\$ 0.7 \mathrm{~m})$ at the IPO, compared to $\$ 3.1 \mathrm{~m}(\$ 0 \mathrm{~m})$ among switchers. Each of the differences between switchers and non-switchers is statistically significant at the $1 \%$ level. 
Focusing on the CEO as the decision-making unit makes sense only if the CEO does not change between the IPO and the SEO. For the sample at hand, $89.9 \%$ of CEOs retain their job at the time of the SEO. ${ }^{9}$ The incumbency rate is significantly higher among non-switchers (96\%) than among switchers (86.6\%) suggesting that a newly appointed CEO selects the SEO underwriter unencumbered by perceptions of performance in the IPO. The multivariate analyses reported in Section III will control for CEO retention.

Broadening the focus to include all directors and executive officers in addition to the CEO yields qualitatively identical results. Similarly, evaluating condition (1) using the holdings of venture capitalists (conditional on VC backing), VCs for non-switchers are more frequently satisfied with the IPO outcome and enjoy significantly greater perceived net wealth gains than VCs for switchers. On the surface, this is surprising if one starts from the premise that venture capitalists, because they are frequent participants in the IPO process, should be less prone to behavioral biases than CEOs for whom the experience is unique. We give further scrutiny to this feature of the data in Section III.

The remainder of Table II summarizes the characteristics of the four elements of satisfaction that make up condition (1): the decision-maker's ownership stake, the amount of stock sold or retained, price revisions relative to the filing range, and initial returns. Pre-IPO ownership stakes and selling behavior at the IPO differ little across the switching and non-switching sub-samples. The only differences that are statistically significant are the CEO's mean pre-IPO equity stake, which is $22.7 \%$ for switchers and $19.3 \%$ for non-switchers, and the lower incidence of selling by directors and executive officers as a group among switchers. All else equal, CEOs with larger shareholdings are more likely to be satisfied with the IPO outcome because large shareholdings increase the left-hand side of condition (1). Thus larger ownership stakes among switchers bias against finding support for a behavioral interpretation.

\footnotetext{
${ }^{9}$ There are 33 cases where the CEO was replaced but instead of leaving the firm became chairman of the board. We code these as CEO changes, though our results are wholly unaffected if we treat them as CEO retentions.
} 
Consistent with the findings of Krigman, Shaw, and Womack (2001) and Cliff and Denis (2003), switchers suffer significantly less underpricing than non-switchers on average (15.4\% vs. $33.3 \%)$. Thus more severe underpricing alone is not likely to drive the switching decision. On the other hand, when switches occur banks may be perceived as having failed to deliver an increase in perceived wealth since the deviation of the offer price from the assumed anchor valuation averages $-2.5 \%$ for switchers compared to $+6.6 \%$ for non-switchers.

\section{E. Other Control Variables}

Prior empirical work suggests a number of reasons why firms switch underwriters. Chief among these are the 'graduation' and 'strategic analyst coverage' effects. The former posits that firms switch if they can persuade a more prestigious bank to underwrite their SEO. The latter suggests that firms switch either because they are dissatisfied with the amount, timeliness, or quality of the IPO underwriter's research output, or to obtain coverage from a more highly ranked sell-side analyst.

The summary statistics in Table III confirm the empirical importance of these effects. Switching firms are taken public by significantly less prestigious underwriters (6.9 vs. 8.2 on the nine-point Carter-Manaster reputation scale). The Carter-Manaster score for the bank hired to underwrite the SEO by a switching firm is 7.6, reflecting graduation to more prestigious underwriters on average. Among the 432 switching firms, $216(50 \%)$ hired more reputable underwriters to manage their SEO.

We examine the issuer's interest in acquiring analyst coverage by defining coverage as having one of the bank's analysts publish at least one research report on the issuer in the two years prior to the SEO. ${ }^{10}$ Our main source of coverage information is $\mathrm{I} / \mathrm{B} / \mathrm{E} / \mathrm{S}$. Where $\mathrm{I} / \mathrm{B} / \mathrm{E} / \mathrm{S}$ indicates that a particular bank did not cover a given sample firm's stock, we ran cross-checks using the Investext collection of analyst reports available online (since 1996) and the news sources available in Factiva (before 1996). Table III shows that $89.7 \%$ of non-switchers receive coverage from their IPO underwriters. When post-IPO coverage is not provided, IPO underwriters are particularly vulnerable to loss of future

\footnotetext{
${ }^{10}$ The results are robust to using a one-year window instead.
} 
underwriting mandates. Only $66.4 \%$ of switchers received coverage from their IPO underwriter prior to their first SEO. This coverage rate is statistically different from the $89.7 \%$ coverage rate among non-switchers. On the other hand, issuers don't obviously reward 'pre-emptive' coverage by switching underwriters. Among switching firms, only $45.6 \%$ received coverage prior to the SEO by the bank chosen to underwrite the SEO. (Though one might presume that the underwriting mandate carried an implicit expectation that coverage would begin following the deal, as in fact it often did.) Indeed, there are only 54 cases (out of 432) in which the SEO underwriter provided pre-SEO coverage while the IPO underwriter did not.

The prior year's all-star analyst rankings published in the October issue of Institutional Investor magazine provide a natural proxy for analyst quality or reputation. IPO underwriters more frequently lose follow-on business when their analyst covering the issuer's stock is not an Institutional Investor all-star (defined as a top 3 or runner-up analyst). However, conditional on the issuer switching underwriters, the frequency with which the SEO underwriter employs an all-star analyst to cover the issuer's stock is not statistically different from that of the IPO underwriter (10\% and $11.1 \%$, respectively). Moreover, the SEO bank employed an all-star analyst while the IPO bank did not in only 30 cases (out of 432).

Finally, we investigate whether the aggressiveness of a bank's analyst recommendations influenced switching decisions. Ljungqvist, Marston, and Wilhelm (2003) define an analyst's relative recommendation as the level of her most recent $\mathrm{I} / \mathrm{B} / \mathrm{E} / \mathrm{S}$ recommendation in the two years prior to the SEO less the median recommendation of other analysts (i.e. 'consensus') during the same window. This measure ranges between -4 and +4 , with positive values indicating relatively more aggressive recommendations. By this measure, IPO underwriters' recommendations for non-switchers were conservative (with an average value of -0.04) relative to those provided for switchers (0.19) and statistically different at the $1 \%$ level. Moreover, switching firms chose banks whose analysts were not only significantly less aggressive than their IPO banks' analysts, but conservative on average (- 
0.08 vs. 0.19 ). These univariate results are consistent with the broader results reported in Ljungqvist, Marston, and Wilhelm suggesting that aggressive analyst behavior neither helps banks retain old clients nor win new ones.

In addition to underwriter quality and analyst behavior, prior work has controlled for firm characteristics. The third and fourth blocks of Table III illustrate that switchers raised a little less money at their IPO and were significantly younger and smaller (as measured by revenue and assets), though they were no more or less profitable at the time of their IPO than non-switchers. ${ }^{11}$

\section{Empirical Results}

We now relate our behavioral proxies to issuing companies' decision whether or not to rehire their IPO underwriter to lead-manage their first follow-on equity offering. In controlling for the 'graduation' and 'strategic analyst coverage' effects, the literature on SEO switching decisions often estimates logit or probit models that include on the right-hand side variables capturing the characteristics of both the IPO underwriter and the SEO underwriter. For instance, Krigman, Shaw, and Womack (2001) relate switching decisions to the net change in underwriter reputation. This is problematic. The characteristics of the bank that an issuer switches to are observed only if there is a switch, and so they are effectively interacted with the dependent variable. For instance, the net change in underwriter reputation is nonzero only if a switch has taken place. Any variable that is zero by definition among non-switchers is a perfect predictor of the switching decision, violating the classical identification assumptions. In such a setting, spurious explanatory power may be attributed to the 'graduation' and 'strategic analyst coverage' variables.

There are two solutions to this specification problem. First, we can estimate probit models that do not condition on information that mechanically covaries with the choice being modeled. This implies

\footnotetext{
${ }^{11}$ Firm characteristics that have been shown empirically not to influence the switching decision include share turnover, the amount of flipping on the first day of trading, and the fee paid to the IPO underwriter (see Cliff and Denis (2003) and Krigman, Shaw, and Womack (2001)). We thus do not include these in our analysis. Fernando, Gatchev, and Spindt (2003) proxy for firm quality using the volatility of pre-SEO stock returns and a dummy for distressed delistings. Neither is significantly related to the switching decision in our sample.
} 
conditioning only on the IPO underwriter's characteristics such as its prestige and provision of analyst services. We estimate such models in Sections III.A through III.C. The conditional logit model associated with McFadden's (1974) choice problem provides an alternative enabling us to also condition on the characteristics of the banks to which an issuer may consider switching. Conditional logit results are reported in Section III.D. The probit and conditional logit results agree with regard to the effect of our behavioral proxies on the switching decision, while they differ somewhat in the estimated effects of bank characteristics.

\section{A. Benchmarking with the Existing Literature}

Column 1 in Table IV benchmarks our findings against those in the literature. It relates the switching decision to firm and offer characteristics as well as the characteristics of the bank underwriting the issuer's IPO, but not the prospect theory proxies. The overall explanatory power of the model is good, in view of the pseudo $R^{2}$ of $23.5 \%$. The results broadly support the 'graduation' and 'strategic analyst' hypotheses.

Consistent with Cliff and Denis (2003) but in contrast to Krigman, Shaw, and Womack (2003), the probability of switching underwriters at the first SEO is related neither to the size of the IPO nor the firm's age when going public. Only one proxy for firm quality, which we borrow from Fernando, Gatchev, and Spindt (2003), has a significant effect on the switching decision: firms with positive earnings per share as of the end of the fiscal year of their SEO are less likely to switch underwriters $(p=0.002) .{ }^{12}$ In common with all prior work, we find that firms are less likely to switch underwriters, the more IPO underpricing they experienced $(p=0.026)$. The effect is large in economic magnitude. A one standard deviation increase in log initial returns decreases the predicted switching probability from $33.1 \%$ to $27.6 \%$, holding all other covariates at their sample means. As conjectured, we also find that the switching probability increases in the log time that has elapsed since the IPO $(p<0.001)$.

\footnotetext{
${ }^{12}$ We have verified that this is a levels effect: the change in EPS relative to the last twelve months prior to the IPO has no bearing on the switching decision. We have also tried other controls for firm quality. For instance, log issuer returns in excess of the CRSP value-weighted Nasdaq index, computed over a variety of pre-SEO windows, have no statistically significant effect in our data.
} 
Among bank characteristics, issuers are less likely to switch, the more reputable the IPO underwriter $(p<0.001)$ and when the IPO underwriter provides research coverage ahead of the SEO $(p<0.001) .{ }^{13}$ Economically, these are the two most significant determinants of issuers' switching decisions. In contrast, the effect of the IPO underwriter's analyst carrying an all-star ranking, while negative as conjectured by Krigman, Shaw, and Womack (2001), is not statistically significant $(p=0.161)$. (It is worth noting that had we instead followed Krigman, Shaw, and Womack by including the net gains in underwriter prestige, research coverage, and all-star analysts in this probit model, we would have found all three to be negatively and significantly related to the switching decision.)

\section{B. Controlling for Decision-Maker Satisfaction}

Column 2 provides results from estimation of the same model but including the binary version of the behavioral proxy for decision-maker satisfaction. In this case, the CEO is taken as the decisionmaker. While the general fit of the model only improves a little, two results stand out. First, the behavioral proxy is inversely related to the likelihood of switching underwriters. The effect is large in economic magnitude: all else equal, CEOs are $7.9 \%$ less likely to switch underwriters at the first SEO when they are satisfied, according to condition (1), with the outcome of their IPO $(p=0.024)$. Second, the effect of IPO underpricing on the issuer's switching decision is no longer statistically significant. Thus, a natural interpretation of the seemingly perverse negative relation between underpricing and the likelihood of switching underwriters is that it reflects an omitted variables bias associated with the failure to control for the decision-maker's exposure to and/or perception of an apparent wealth loss.

The model shown in column 3 uses the alternative dollar-valued specification of the behavioral proxy for satisfaction, in a logarithmic transformation. ${ }^{14}$ The greater their perceived wealth gain, the less likely are CEOs to switch underwriters $(p=0.015)$. The effect is again large economically: a one

\footnotetext{
${ }^{13}$ To ensure comparability with extant models of the switching decision, we do not control for the strength of the IPO underwriter's analyst recommendation. This does not affect our results. Consistent with Ljungqvist, Marston, and Wilhelm (2003), we find that firms are more likely to switch, the more aggressive their IPO underwriter's recommendation. ${ }^{14}$ Since the dollar-valued version of the behavioral proxy can be zero or negative, we transform it such that it equals $\ln (1+X)$ if $X \geq 0$ and $-\ln (1-X)$ if $X<0$. This transform is commonly used in accounting research.
} 
standard deviation increase in this proxy is associated with a decrease in the predicted switching probability from $33.2 \%$ to $28.9 \%$, holding all other covariates at their sample means. The effect is about one third of the effect of a one standard deviation increase in the IPO underwriter's CarterManaster rank, the economically largest determinant of the switching decision in our models.

The results reported in columns 4 and 5 indicate robustness to broadening the decision-making unit to include all directors and executive officers (in addition to the CEO). The estimated coefficients are somewhat larger economically and stronger statistically. The only alternative specification of the decision-making unit to which the results are sensitive is that which treats the venture capitalist as the main decision-maker for VC-backed IPOs, reported in columns 6 and 7. Neither the binary nor the dollar-valued proxy for the VCs' satisfaction with the IPO has a significant effect on the switching decision. Given their regular participation in the IPO process, VCs may be less inclined toward behavioral biases. Alternatively, VCs may not be particularly influential in the selection of an underwriter subsequent to the IPO.

\section{Assessing the Plausibility of the Behavioral Interpretation}

Recall that for $89.9 \%$ of the sample issuers, the CEO does not change from the IPO to the SEO. The cases in which the CEO leaves the company provide a natural experiment for examining the plausibility of our interpretation of the behavioral proxies. In such cases, the behavioral proxies for satisfaction with the IPO do not reflect the experience of the current decision-maker and thus there is no obvious prediction of a relation between these proxies and the decision to switch underwriters at the SEO. As the results in Table V show, this is indeed the case. For those cases in which the CEO changes between the IPO and SEO, the behavioral proxies for satisfaction have a much smaller and statistically insignificant effect on the decision to switch underwriters ( $p=0.809$ for the binary proxy and $p=0.870$ for the dollar-valued specification). Instead, the probability of switching is related to the issuer's quality and the absence of research coverage from the IPO underwriter.

Arguably, a CEO may be less prone to behavioral biases, the more experienced and skilled he 
is. To examine this conjecture, we hand-collect biographical information for all CEOs still in post at the time of the SEO. IPO prospectuses disclose CEO age, employment history, and membership of other companies' boards. Frequently, they also disclose educational background, though this is not mandatory. In Table VI, we sort CEOs into those who had been CEO of another firm prior to joining the sample company ('experienced' CEOs) and those who had not. It is conceivable that experience measured in this way is correlated with higher liquid net wealth. Among the 250 'experienced' CEOs, our behavioral proxies do not influence the likelihood of a switch (see columns 1 and 3). Instead, the effect of the behavioral proxies is concentrated among the less experienced CEOs (see columns 2 and 4). Similar results obtain when we sort by prior board experience or whether the CEO had previously founded another company (not shown).

In columns 5 through 8 of Table VI, we sort CEOs according to their educational background. For CEOs who hold a postgraduate degree (PhD, MD, JD, MA, MS, or MBA), we find no significant relation between the behavioral proxies and the switching decision. However, just over half the CEOs do not disclose their educational background, so this result must be interpreted with caution.

IPO underpricing reached extreme levels during the 'dot-com bubble' of 1999 and early 2000 (see Ljungqvist and Wilhelm (2003)). Nevertheless, condition (1) classifies a majority of issuers in those years as satisfied due to the predominantly positive and unusually large price revisions they experienced. The bursting of the 'dot-com bubble' in the second quarter of 2000 was followed by allegations of investment bank wrong-doing. For instance, investment bankers had in some cases allocated heavily underpriced stock to executives at other firms in the hope of winning their future underwriting business, a practice known as spinning. Such revelations, combined with often extreme share price collapses, could arguably have served as 'eye-openers', reversing an issuer's positive perception of the IPO outcome as captured by our behavioral proxies. If so, we would expect the behavioral proxies to have little explanatory power following the bursting of the 'bubble'.

In Table VII, we interact the behavioral proxies with a dummy variable identifying firms that 
went public during the 'bubble' period (1999Q1 to 2000Q2) and completed their SEO after the 'bubble' burst. For both versions of the proxy, the interaction effect is positive, attenuating the negative effect of satisfaction on the switching decision, and at least marginally significant. Overall, we cannot reject the hypothesis that the combined effect through the behavioral proxy itself and the interaction term is zero for SEOs completed after the second quarter of $2000(p=0.506$ and $p=0.437$ for the binary and dollar-valued measure, respectively). One plausible interpretation of this result is that fallout from the 'dot-com bubble' bursting substantially undermined any goodwill IPO underwriters built up during this period.

An alternative interpretation of the behavioral proxies is that they merely capture the effect of the underwriter's bookbuilding activities. Perhaps decision-makers interpret positive revisions in the value of their offerings (which occur when $O P$ - midpoint $>0$ ) as evidence of the underwriter's skill in placing their stock with investors who are willing to pay the most for it. Retaining such an underwriter for follow-on offers could thus be entirely rational. To see if this is driving our results, we include proceeds revisions alongside our two behavioral proxies. These are highly correlated (the Spearman rank correlations exceed 70\%) so we expect standard errors to increase. The results are reported in columns 3 and 4 of Table VII. The coefficients estimated for proceeds revisions are never significant, whereas we continue to find a negative effect on the switching probability from both the binary $(p=0.10)$ and the dollar-valued version $(p=0.022)$ of the behavioral proxy. ${ }^{15}$

In summary, the results reported in Tables IV through VII are broadly consistent with the interpretation of the behavioral proxies as measures of decision-maker satisfaction. Treating the CEO as the key decision-maker yields the conclusion that satisfaction with the outcome of the IPO diminishes the likelihood of switching underwriters at the SEO. This result does not hold in cases where the CEO changes following the IPO or under a specification that treats venture capitalists as the relevant decision-making unit. The result is characteristic of normal market conditions and is reversed

\footnotetext{
${ }^{15}$ Similar results obtain if we use price revisions instead of proceeds revisions.
} 
following the bursting of the 'dot-com bubble' in 2000Q2.

\section{A Conditional Logit Specification Controlling for Decision-Maker Satisfaction}

The probit results reported so far do not control for the characteristics of banks competing with the IPO underwriter to lead-manage the SEO. It is therefore conceivable that our behavioral proxies pick up the effect of these omitted variables, though exactly why they should be related is not obvious a priori. To investigate this possibility further, we estimate conditional logit models of the issuer's choice among competing banks.

We assume issuers choose their SEO lead-manager from among a set of two banks: the IPO underwriter and a 'new bank'. Which new bank? Where a switch has taken place, we assume that the chosen bank is the one that maximizes the issuer's utility. Under the Independence of Irrelevant Alternatives axiom, we can ignore for estimation purposes all the other banks that could have been but were not chosen. If no switch has taken place, we must specify an alternative choice of bank. Since we do not observe which banks an issuer considered, we model three scenarios that differ in the characteristics (i.e. prestige, research coverage, and analyst reputation) attributed to the alternative bank. Specifically, we assume that the alternative bank has the same characteristics as either 1) the IPO underwriter, 2) the average bank, or 3) the best bank. Scenario 1) assumes that the best available alternative for a non-switcher was no better than its IPO underwriter. It thus examines the influence of the issuer's attributes, including our behavioral proxies, holding the issuer on its indifference curve with respect to bank characteristics. The parameters for scenario 2) are a Carter-Manaster rank of 7.25, no research coverage, and the absence of an all-star analyst. For scenario 3), they are a rank of 9.1 (the highest possible), coverage, and the presence of an all-star analyst.

Let $\mathrm{y}_{\mathrm{ij}}$ be an indicator variable for issuer $i$ 's actual choice. Issuers can choose between the IPO underwriter $(j=1)$ and another bank $(j=2)$ such that $\mathrm{y}_{\mathrm{ij}}=1$ if issuer $i$ chooses bank $j$, and zero otherwise. Thus for every issuer $i$ we have a tuplet $\left\{y_{\mathrm{i} 1}, \mathrm{y}_{\mathrm{i} 2}\right\}$ that either equals $\{1,0\}$ or $\{0,1\}$. The tuplet $\{0,1\}$ corresponds to switching underwriters. We relate the probability of observing these choices to two 
classes of variables: attributes of the choices available to the $i$ th issuer and attributes of the $i$ th issuer. Our set of choice attributes includes three variables: the prestige of the bank measured using the Carter-Manaster tombstone rankings, a dummy equaling 1 if the bank's analyst covered the issuer's stock at any time during the two years prior to the SEO, and a dummy equaling 1 if the analyst was an all-star at the time. Note that these variables vary with the choice made. For instance, a representative tuplet of the banks' Carter-Manaster tombstone rankings for issuer $i$ might be $\{5,9\}$.

Our set of issuer attributes consists of the five firm and offer characteristics included in our probit models, plus our behavioral proxies. Note that while issuer attributes vary across issuers, they are constant for each issuer whichever bank is chosen. Conditional logit models estimate the effect of issuer attributes by interacting such variables with a dummy for the choice in hand ${ }^{16}$ Clearly, with only two choices, it does not matter whether we use choice 1 or its complement, choice 2 . We interact the issuer attributes with a dummy identifying the new bank $(j=2)$. The coefficients are interpreted as estimates of the effect of issuer attributes on the likelihood that the issuer switches banks.

Table VIII presents the results. For each of the three scenarios, we estimate two specifications, using either the binary or the dollar-valued behavioral proxy. The issuer attributes have similar effects across all six models. In contrast to our probit results, we find that firms with larger IPOs are significantly less likely to hire a new bank for their SEO (they are less likely to switch). We also find some evidence that older IPO firms are less likely to switch (in Scenarios 1 and 2). As before, firms are less likely to switch if they have positive EPS at the time of the SEO, the more IPO underpricing they suffered (except in Scenario 2), and the less time has elapsed since the IPO.

The effects of the attributes of the choice (i.e. the bank characteristics) vary across the scenarios, that is, depending on who we assume the alternative bank to be. In scenarios 1) and 2), a bank is more likely to be chosen the higher its Carter-Manaster ranking. Providing research coverage is beneficial only in Scenario 2); in the other scenarios, a bank is actually less likely to be chosen when it provides

\footnotetext{
${ }^{16}$ See Greene (2003), p. 720.
} 
coverage. While counterintuitive, this finding confirms the univariate result in Table III suggesting that conditional on switching, firms choose banks that are less likely to provide coverage than their IPO underwriter (with a coverage rate of $45.6 \%$ vs. $66.4 \%$ ). Having an all-star analyst cover the issuer's stock does not affect a bank's chances of being chosen, except in Scenario 3) where the effect is negative. This too is broadly consistent with Table III.

Controlling for these effects, we find that issuers are significantly less likely to switch to a new bank if their CEO is classified as satisfied with the IPO outcome. This result holds for both the binary and the dollar-valued version of our proxy, and varies little across the three scenarios. Thus, omitting the characteristics of the banks an issuer may consider switching to does not appear to bias our inference regarding the behavioral proxies.

\section{E. Do Underwriters Benefit from Behavioral Biases?}

Loughran and Ritter (2002) argue that banks underwriting IPOs stand to gain from the decisionmaker's behavioral biases - over and above retaining the firm's custom in the future. An obvious source of gain is the potential for underpricing the issuer's stock by more than is necessary to complete the offering, to the benefit of institutional investors who may, in turn, share the gains with the bank via excess trading commissions. ${ }^{17}$ Consistent with this notion, the initial return averages $41.4 \%$ among issuers classified as satisfied with the outcome of the IPO, as compared to $6.1 \%$ among the rest. Determining whether the bank actually benefits from larger initial returns requires data on its relationships with the institutional investors to whom IPO shares are allocated. Such data are not publicly available.

Conceivably, the bank may exploit the decision-maker's satisfaction with the IPO by charging an excessive fee for underwriting the follow-on equity offer. We investigate this possibility by estimating a standard model of the determinants of the SEO spread that additionally controls for the issuer's

\footnotetext{
${ }^{17}$ For instance, in 2002 CSFB was fined $\$ 100$ million for "taking millions of dollars from customers in inflated commissions in exchange for allocations of 'hot' Initial Public Offerings (IPOs)" between April 1999 and June 2000. (NASD Regulation, Inc. news release dated January 22, 2002.)
} 
satisfaction. Following Altinkilic and Hansen (2000), we model SEO spreads as decreasing in the amount raised at the SEO (in log real dollars) and firm quality (measured using the volatility of daily stock returns estimated over the 230 trading days ending 20 days before the SEO,${ }^{18}$ the EPS dummy used earlier, and the firm's real log market capitalization as of the month-end prior to the SEO date), and increasing in aggregate primary market activity (measured as the log real amount raised in all IPOs and SEOs in the three calendar months preceding the SEO).

The least-squares estimates are reported in Table IX. The sample size decreases by the 24 firms for which prospectuses fail to report the spread paid to the SEO underwriter. The Altinkilic-Hansen controls confirm that SEO spreads are significantly lower for larger offers and higher-quality issuers (that is, those with lower volatility, positive earnings, and larger market capitalizations), and significantly higher the more active is the primary equity market. Controlling for these effects, column 1 shows that SEO spreads are on average 12 basis points higher when the CEO is classified as satisfied with the outcome of the IPO ( $p=0.002)$. The average SEO raises $\$ 116.8$ million, so satisfied CEOs pay an excess commission of $\$ 140,000$ on average. Thus satisfaction with the IPO outcome is associated with both a reduced likelihood of switching underwriters for the first SEO and paying higher fees for SEO underwriting services.

The model shown in column 2 uses the dollar-valued proxy for issuer satisfaction, and allows its slope to depend on whether the CEO is classified as satisfied with the IPO. In instances of dissatisfaction with the outcome, the SEO spread decreases significantly in the net dollar-valued loss the CEO perceived at the time of the IPO $(p=0.001)$. When the CEO was satisfied, the SEO spread increases significantly $(p<0.001)$, by about 30 basis points for a one-standard-deviation increase in the perceived net dollar-valued gain. These results suggest that satisfied CEOs are a soft touch for banks underwriting their first SEO. They do not show whether their IPO underwriter reaps benefits from their satisfaction because we have not distinguished between firms that switched underwriters and

\footnotetext{
${ }^{18}$ As the CRSP tapes for 2003 aren't yet available, we use share price data provided by nasdaq.com where necessary.
} 
firms that did not. Models 3 and 4 re-estimate model 2 for non-switchers and switchers, respectively. As expected, the behavioral proxies are significant only among non-switchers.

\section{Conclusion}

We develop a behavioral proxy for the IPO decision-maker's satisfaction with an IPO underwriter's performance. The proxy is derived directly from the prospect theory argument for IPO underpricing in Loughran and Ritter (2002). It measures whether, and to what degree, the CEO responsible for an IPO was 'satisfied' with the underwriter's performance given the CEO's wealth loss due to underpricing and his (perceived) wealth gain due to offer price revisions. We then examine which bank the IPO firm chooses as underwriter for its first seasoned equity offering (SEO) and test whether the CEO is more likely to retain the IPO underwriter to lead-manage the follow-on offer when the behavioral proxy indicates that he was satisfied with the IPO outcome.

If IPO decision-makers reveal their preferences through subsequent decisions, the plausibility of the underpinnings of Loughran and Ritter's behavioral story can be examined fairly directly by this method. From the perspective of expected utility theory, the behavioral proxy should have no explanatory power. We find, however, that IPO firms are significantly more likely to switch underwriters after the IPO when the behavioral proxy indicates that they were dissatisfied with the IPO underwriter's performance, controlling for other known factors.

The behavioral interpretation is more plausible when the issuer's CEO, with whom the choice of underwriter ultimately rests, is still in charge at the time of the SEO. Consistent with this interpretation, the explanatory power of our behavioral proxy is concentrated among firms that retained their CEOs. The effect is strongest among relatively less experienced CEOs. The result also holds when the behavioral proxy is measured for the group of senior executives collectively. On the other hand, switching behavior is not influenced by a venture capitalist's satisfaction with the IPO outcome. Given their regular participation in the IPO process, VCs may be less inclined toward behavioral biases (or they may not be particularly influential in the underwriter selection decision 
after the IPO). Finally, underwriters also appear to benefit from behavioral biases in the sense that they extract higher fees for subsequent transactions when these involve decision-makers deemed satisfied.

Our tests do not speak directly to whether and to what degree behavioral biases determine patterns in IPO initial returns. In the sense that the tests suggest there is explanatory power in the behavioral model, they do shed light on the plausibility of the underlying structure necessary for such a linkage to exist. An explicit characterization and test of this linkage remains a substantial challenge for future research. 


\section{References}

Altinkilic, O., Hansen, R.S., 2000. Are there economies of scale in underwriting fees? Evidence of rising external financing costs. Review of Financial Studies 13, 191-218.

Anand, B., Galetovic, A., 2000. Information, non-excludability and financial market structure. Journal of Business 73, 357-402.

Baron, D.P., 1982. A model of the demand for investment banking advising and distribution services for new issues. Journal of Finance 37, 955-976.

Benveniste, L.M., Spindt, P.A., 1989. How investment bankers determine the offer price and allocation of new issues. Journal of Financial Economics 24, 343-61.

Benveniste, L.M., Ljungqvist, A., Wilhelm, W.J., Yu, X., 2003. Evidence of information spillovers in the production of investment banking services. Journal of Finance 58, 577-608.

Biais, B., Bossaerts, P. Rochet, J.-C., 2002. An optimal IPO mechanism. Review of Economic Studies 69, 117-146.

Boot, A., Thakor, A.V., 2000. Can relationship banking survive competition? Journal of Finance 55, 679-713.

Carter, R.B., 1992. Underwriter reputation and repetitive public offerings. Journal of Financial Research 15, 341-354.

Carter, R.B., Manaster, S., 1990. Initial public offerings and underwriter reputation. Journal of Finance 45, 1045-1067.

Cliff, M.T., Denis, D.J., 2003. Do IPO firms purchase analyst coverage with underpricing? Journal of Finance, forthcoming.

Corwin, S.A., Schultz, P.A., 2003. The role of IPO underwriting syndicates: Pricing, information production, and underwriter competition. Unpublished working paper, University of Notre Dame.

Fernando, C.S., Gatchev, V.A., Spindt, P.A., 2003. Wanna dance? How firms and underwriters choose each other, unpublished working paper, Tulane University.

Greene, W.H., 2003. Econometric Analysis. Fifth Edition. Prentice Hall.

Hanley, K., 1993. The underpricing of initial public offerings and the partial adjustment phenomenon. Journal of Financial Economics 34, 231-50.

Heckman, J., 1979. Sample selection bias as a specification error. Econometrica 47, 153-162.

Jenkinson, T., Ljungqvist, A., 2001. Going Public: The Theory and Evidence on How Companies Raise Equity Finance. Second edition. Oxford University Press.

Kahneman, D., Tversky, A., 1979. Prospect theory: An analysis of decision under risk. Econometrica 47, 263-291. 
Krigman, L., Shaw, W.H., Womack, K.L., 2001. Why do firms switch underwriters? Journal of Financial Economics 60, 245-284.

Ljungqvist, A.P., Marston, F., Wilhelm, W.J., 2003. Competing for securities underwriting mandates: Banking relationships and analyst recommendations. Unpublished working paper, New York University.

Ljungqvist, A., Wilhelm, W.J., 2003. IPO pricing in the dot-com bubble. Journal of Finance 58, 723752.

Loughran, T., Ritter, J.R., 2002. Why don't issuers get upset about leaving money on the table in IPOs? Review of Financial Studies 15, 413-443.

Loughran, T., Ritter, J.R., 2003. Why has IPO underpricing changed over time? Unpublished working paper, University of Florida.

McFadden, D., 1974. Conditional logit analysis of qualitative choice behavior. In: P. Zarembka (ed.), Frontiers in Econometrics, 105-142. Academic Press, New York

Nanda, V., Yun, Y., 1997. Reputation and financial intermediation: An empirical investigation of the impact of IPO mispricing on underwriter market value. Journal of Financial Intermediation 6, 3963.

Petersen, M.A., Rajan, R.G., 1994. The benefits of lending relationships: Evidence from small business data. Journal of Finance 49, 3-37.

Petersen, M.A., Rajan, R.G., 1995. The effect of credit market competition on lending relationships. Quarterly Journal of Economics 110, 407-443.

Ritter, J., Welch, I., 2002. A review of IPO activity, pricing, and allocations. Journal of Finance 57, 1795-1828.

Rock, K. 1986. Why new issues are underpriced. Journal of Financial Economics 15, 187-212.

Shefrin, H.M., Statman, M., 1984. Explaining investor preferences for cash dividends. Journal of Financial Economics 13, 253-282.

Thaler, R., 1980. Toward a positive theory of consumer choice. Journal of Economic Behavior and Organization 1, 39-60.

Thaler, R., 1985. Mental accounting and consumer choice. Marketing Science 4, 199-214. 


\section{Table I. Descriptive Sample Statistics}

The sample consists of the 3,435 non-financial common-stock IPOs completed in the U.S. between January 1993 and December 2000 with offer prices of at least \$5/share. Post-IPO seasoned equity offers (SEOs) are identified using three company identifiers: SDC company id, I.R.S. tax numbers, and company name. Filing size is the first disclosure of intended issue size from S.E.C. registrations. Offer size is offer price times number of shares sold (excluding the over-allotment option). The initial return is measured as the first-day closing price over the offer price, less one. The filing midpoint price is the midpoint of the first indicative price range filed with the S.E.C. In the context of accounting data, LTM stands for the 'last twelve month' accounting period prior to the IPO. We use Jay Ritter's updated Carter-Manaster (1990) ranks as a measure of underwriter reputation. These range from 0 to 9.1 , with larger numbers denoting more prestigious banks. 'Insiders' are directors and executive officers as a group, as identified in the ownership section of the IPO prospectus. VC backing information comes from the prospectuses and includes backing by either venture capitalists or private equity (middle-market, buy-out, merchant banking) funds. The test statistics reported in the last column are for $t$-tests of equal means, $\chi^{2}$-tests of equal medians, and $Z$-tests of equal proportions, as required. We use ${ }^{* * *},{ }^{* *}$, and ${ }^{*}$ to denote significance at the $1 \%, 5 \%$, and $10 \%$ level (two-sided), respectively.

\begin{tabular}{|c|c|c|c|c|c|}
\hline & & \multirow{2}{*}{$\begin{array}{l}\text { Whole } \\
\text { sample }\end{array}$} & \multicolumn{2}{|c|}{$\begin{array}{l}\text { Subsequent SEO by } \\
\text { Sept. 30, 2003? }\end{array}$} & \multirow{2}{*}{$\begin{array}{c}\text { Test of } \\
\text { equal means, } \\
\text { medians, or } \\
\text { fractions }\end{array}$} \\
\hline & & & Yes & No & \\
\hline Number of observations & & 3,435 & 1,203 & 2,232 & \\
\hline IPO filing size (\$m) & mean & 71.8 & 83.5 & 65.5 & $-2.10^{* *}$ \\
\hline IPO offer size $(\$ m)$ & mean & 76.3 & 88.3 & 69.8 & $-2.03^{* *}$ \\
\hline age at IPO (years) & mean & 14.4 & 15.2 & 14.0 & $-1.73^{*}$ \\
\hline IPO initial return (\%) & mean & 28.1 & 26.9 & 28.7 & 0.98 \\
\hline price change from filing midpoint to offer $(\%)$ & mean & 3.9 & 3.3 & 4.1 & 0.91 \\
\hline LTM revenue $(\$ \mathrm{~m})$ & mean & 163.5 & 217.9 & 134.1 & $-1.99^{* *}$ \\
\hline LTM revenue $(\$ \mathrm{~m})$ & median & 25.4 & 35.3 & 21.1 & $59.77^{* * *}$ \\
\hline pre-IPO book value of assets $(\$ \mathrm{~m})$ & mean & 170.9 & 250.9 & 130.4 & $-3.06^{* * *}$ \\
\hline pre-IPO book value of assets $(\$ \mathrm{~m})$ & median & 23.8 & 31.4 & 20.5 & $50.77^{* * *}$ \\
\hline LTM net income $(\$ m)$ & mean & -3.9 & -4.9 & -3.5 & 0.44 \\
\hline LTM net income (\$m) & median & 0.3 & 0.8 & 0.2 & $13.22^{* * *}$ \\
\hline fraction of IPO firms w/ LTM EPS $<0$ (\%) & fraction & 45.0 & 41.2 & 47.1 & $3.29^{* * *}$ \\
\hline IPO underwriter's Carter-Manaster rank & mean & 7.3 & 7.7 & 7.0 & $-8.87^{* * *}$ \\
\hline CEO pre-IPO equity stake (\%) & mean & 21.8 & 20.5 & 22.5 & $2.12^{* *}$ \\
\hline fraction of CEOs selling stock in IPO (\%) & fraction & 12.9 & 13.6 & 12.5 & -0.98 \\
\hline pre-IPO insider equity stake (\%) & mean & 62.2 & 61.9 & 62.4 & 0.45 \\
\hline fraction of insiders selling stock in IPO (\%) & fraction & 25.1 & 27.8 & 23.7 & $-2.65^{* * *}$ \\
\hline fraction of venture-backed IPO firms (\%) & fraction & 51.4 & 57.1 & 48.3 & $4.90^{* * *}$ \\
\hline VCs' pre-IPO equity stake (\%) & mean & 39.3 & 39.3 & 39.4 & 0.93 \\
\hline fraction of VCs selling stock in IPO (\%) & fraction & 19.0 & 24.4 & 15.5 & $-4.69^{* * *}$ \\
\hline
\end{tabular}




\section{Table II. The Behavioral Proxies}

A firm is classified as switching underwriters if it doesn't rehire its IPO lead manager, or relevant successor entities, to lead-manage its first post-IPO seasoned equity offer (SEO). Successor entities are identified using the information in Corwin and Schultz (2003) and Ljungqvist, Marston, and Wilhelm (2003). If the IPO was lead-managed by multiple banks, we deem the firm to switch underwriters if it doesn't rehire at least one of the IPO underwriters. The fraction of decision-makers deemed 'satisfied' with the IPO outcome is computed by evaluating expression (1) in the text. The decision-maker's net perceived wealth gain is computed as the left-hand side of expression (1) less the right-hand side. We manually inspect SEO prospectuses (and where missing proxy statements) to ascertain if the CEO in charge at the time of the IPO is still in charge at the time of the SEO. The final two blocks contain statistics on the same variables introduced in Table I. The test statistics reported in the last column are for $t$-tests of equal means, $\chi^{2}$-tests of equal medians, and Z-tests of equal proportions, as required. We denote significance at the $1 \%$ and $5 \%$ level by ${ }^{* * *}$ and ${ }^{* *}$, respectively.

\begin{tabular}{|c|c|c|c|c|c|}
\hline & & & $\begin{array}{r}\text { Switch } \\
\text { underw }\end{array}$ & & $\begin{array}{c}\text { Test of } \\
\text { equal means, }\end{array}$ \\
\hline & & $\begin{array}{r}\text { SEO } \\
\text { sample }\end{array}$ & Yes & No & $\begin{array}{l}\text { medians, or } \\
\text { fractions }\end{array}$ \\
\hline Number of observations & & 1,203 & 432 & 771 & \\
\hline$\%$ of CEOs classified as 'satisfied' with the IPO & fraction & 58.9 & 48.8 & 64.5 & $5.28^{* * *}$ \\
\hline CEO's net perceived wealth gain $(\$ \mathrm{~m})$ & mean & 14.9 & 3.1 & 21.5 & $3.44^{* * *}$ \\
\hline CEO's net perceived wealth gain $(\$ \mathrm{~m})$ & median & 0.3 & 0.0 & 0.7 & $38.20^{* * *}$ \\
\hline fraction of CEOs still in job at time of SEO (\%) & fraction & 89.9 & 83.8 & 93.4 & $5.31^{* * * *}$ \\
\hline$\%$ of insiders classified as 'satisfied' with the IPO & fraction & 61.5 & 50.7 & 67.6 & $5.77^{* * *}$ \\
\hline insiders' net perceived wealth gain $(\$ \mathrm{~m})$ & mean & 66.0 & 8.2 & 98.6 & $4.02^{* * *}$ \\
\hline insiders' net perceived wealth gain $(\$ \mathrm{~m})$ & median & 2.1 & 0.1 & 6.1 & $60.00^{* * *}$ \\
\hline$\%$ of VCs classified as 'satisfied' with the IPO & fraction & 63.2 & 51.3 & 69.1 & $4.54^{* * *}$ \\
\hline VCs' net perceived wealth gain $(\$ \mathrm{~m})$ & mean & 56.8 & 7.4 & 81.6 & $3.90^{* * *}$ \\
\hline VCs' net perceived wealth gain $(\$ \mathrm{~m})$ & median & 2.7 & 0.1 & 6.7 & $34.11^{* * *}$ \\
\hline CEO pre-IPO equity stake (\%) & mean & 20.5 & 22.7 & 19.3 & $-2.24^{* *}$ \\
\hline fraction of CEOs selling stock in IPO (\%) & fraction & 13.6 & 13.2 & 13.9 & 0.33 \\
\hline pre-IPO insider equity stake (\%) & mean & 61.9 & 62.9 & 61.3 & -0.87 \\
\hline fraction of insiders selling stock in IPO (\%) & fraction & 27.8 & 24.3 & 29.7 & $2.01^{* *}$ \\
\hline fraction of venture-backed IPO firms (\%) & fraction & 57.1 & 52.8 & 59.5 & $2.27^{* *}$ \\
\hline VCs' pre-IPO equity stake (\%) & mean & 39.3 & 40.6 & 38.6 & -0.98 \\
\hline fraction of VCs selling stock in IPO (\%) & fraction & 24.5 & 25.4 & 24.0 & -0.42 \\
\hline IPO initial return $(\%)$ & mean & 26.9 & 15.4 & 33.3 & $6.18^{* * *}$ \\
\hline price change from filing midpoint to offer (\%) & mean & 3.3 & -2.5 & 6.6 & $6.86^{* * *}$ \\
\hline
\end{tabular}




\section{Table III. Descriptive Statistics for Switchers and Non-Switchers}

A firm is classified as switching underwriters if it doesn't rehire its IPO lead manager, or relevant successor entities, to lead-manage its first post-IPO seasoned equity offer (SEO). Successor entities are identified using the information in Corwin and Schultz (2003) and Ljungqvist, Marston, and Wilhelm (2003). If the IPO was lead-managed by multiple banks, we deem the firm to switch underwriters if it doesn't rehire at least one of the IPO underwriters. The first, third, and fourth blocks contain statistics on the same variables introduced in Table I. The second block relates to analyst coverage (defined as the analyst issuing at least one report in the two years prior to the SEO), the presence of all-star analysts (i.e. ranked among the top 3 or runner-up analysts by Institutional Investor magazine in its previous October issue), and the bank's most recent recommendation relative to consensus (with positive numbers indicating above-consensus recommendations). The test statistics reported in the last column are for $t$-tests of equal means, $\chi^{2}$-tests of equal medians, and $Z$-tests of equal proportions, as required. We denote significance at the $1 \%$ and $5 \%$ level by ${ }^{* * *}$ and ${ }^{* *}$, respectively.

\begin{tabular}{|c|c|c|c|c|c|}
\hline & & & $\begin{array}{r}\text { Switc } \\
\text { underw }\end{array}$ & & $\begin{array}{c}\text { Test of } \\
\text { equal means, }\end{array}$ \\
\hline & & $\begin{array}{l}\text { SEO } \\
\text { sample }\end{array}$ & Yes & No & $\begin{array}{l}\text { medians, or } \\
\text { fractions }\end{array}$ \\
\hline Number of observations & & 1,203 & 432 & 771 & \\
\hline IPO underwriter's Carter-Manaster rank & mean & 7.7 & 6.9 & 8.2 & $12.37^{* * *}$ \\
\hline SEO underwriter's Carter-Manaster rank & mean & 8.0 & 7.6 & 8.2 & $6.16^{* * *}$ \\
\hline fraction w/ coverage by IPO underwriter (\%) & fraction & 81.4 & 66.4 & 89.7 & $9.95^{* * *}$ \\
\hline fraction w/ coverage by SEO underwriter $(\%)$ & fraction & 73.6 & 45.6 & 89.3 & $16.49^{* * *}$ \\
\hline fraction where IPO bank's analyst is all-star $(\%)$ & fraction & 19.7 & 11.1 & 24.5 & $5.61^{* * * *}$ \\
\hline fraction where SEO bank's analyst is all-star (\%) & fraction & 19.3 & 10.0 & 24.5 & $6.14^{* * * *}$ \\
\hline IPO bank's relative recommendation & mean & 0.01 & 0.19 & -0.04 & $-5.10^{* * *}$ \\
\hline SEO bank's relative recommendation & mean & -0.04 & -0.08 & -0.03 & 1.01 \\
\hline IPO filing size $(\$ \mathrm{~m})$ & mean & 83.5 & 66.3 & 93.1 & 1.25 \\
\hline IPO offer size $(\$ \mathrm{~m})$ & mean & 88.3 & 70.5 & 98.3 & 1.22 \\
\hline age at IPO (years) & mean & 15.2 & 14.0 & 16.0 & 1.60 \\
\hline LTM revenue $(\$ \mathrm{~m})$ & mean & 217.9 & 264.3 & 191.9 & -0.75 \\
\hline LTM revenue $(\$ \mathrm{~m})$ & median & 35.3 & 25.7 & 43.3 & $20.67^{* * *}$ \\
\hline pre-IPO book value of assets (\$m) & mean & 250.9 & 202.9 & 274.8 & 0.76 \\
\hline pre-IPO book value of assets $(\$ \mathrm{~m})$ & median & 31.4 & 26.3 & 37.0 & $9.64^{* * * *}$ \\
\hline LTM net income $(\$ \mathrm{~m})$ & mean & -4.9 & 3.1 & -9.0 & -1.46 \\
\hline LTM net income (\$m) & median & 0.8 & 0.6 & 0.9 & 1.69 \\
\hline fraction of IPO firms $\mathrm{w} / \mathrm{LTM}$ EPS $<0(\%)$ & fraction & 41.2 & 44.2 & 39.6 & -1.57 \\
\hline
\end{tabular}




\section{Table IV. Probit Models of the Switching Decision}

We relate a firm's decision whether to switch underwriters between the IPO and the first SEO to the firm and bank characteristics described in Table III, a dummy variable that equals 1 if the firm reported positive earnings per share for the fiscal year in which the SEO took place, and our behavioral proxies from Table II. Since the dollar-valued version of the behavioral proxy can be zero or negative, we transform it such that it equals $\ln (1+X)$ if $X \geq 0$ and $-\ln (1-X)$ if $X<0$. In columns 3 and 5, the sample size declines by six observations for which the dollar-valued proxy of issuer satisfaction cannot be computed due to division by zero. The models in columns 6 and 7 are estimated in the sub-sample of venture-backed IPOs. Intercepts are not shown. White heteroskedasticity-consistent standard errors are reported in italics. We denote significance at the $1 \%$ and $5 \%$ level by ${ }^{* * *}$ and ${ }^{* *}$, respectively.

\begin{tabular}{|c|c|c|c|c|c|c|c|}
\hline & \multicolumn{7}{|c|}{ Dependent variable: indicator $=1$ if firm switches underwriter } \\
\hline & $(1)$ & $(2)$ & (3) & (4) & $(5)$ & $(6)$ & (7) \\
\hline \multicolumn{8}{|l|}{ Firm and offer characteristics } \\
\hline \multirow[t]{2}{*}{$\log$ IPO filing size $(\$ m)$} & -0.002 & -0.018 & 0.009 & -0.016 & 0.005 & 0.003 & 0.004 \\
\hline & 0.057 & 0.058 & 0.058 & 0.058 & 0.058 & 0.089 & 0.089 \\
\hline \multirow[t]{2}{*}{$\ln (1+$ age at IPO $)$} & -0.054 & -0.057 & -0.055 & -0.056 & -0.055 & -0.032 & -0.035 \\
\hline & 0.050 & 0.051 & 0.051 & 0.051 & 0.051 & 0.072 & 0.072 \\
\hline \multirow{2}{*}{$=1$ if EPS $>0$} & $-0.282^{* * *}$ & $-0.269^{* * *}$ & $-0.256^{* * *}$ & $-0.263^{* * *}$ & $-0.249^{* * *}$ & $-0.312^{* * *}$ & $-0.303^{* * *}$ \\
\hline & 0.091 & 0.092 & 0.092 & 0.092 & 0.093 & 0.117 & 0.118 \\
\hline \multirow[t]{2}{*}{$\ln (1+$ initial IPO return $)$} & $-0.467^{* *}$ & -0.255 & -0.188 & -0.222 & -0.119 & -0.247 & -0.173 \\
\hline & 0.210 & 0.221 & 0.230 & 0.220 & 0.226 & 0.281 & 0.288 \\
\hline \multirow[t]{2}{*}{$\ln$ (days from IPO to SEO) } & $0.642^{* * *}$ & $0.646^{* * *}$ & $0.657^{* * *}$ & $0.648^{* * *}$ & $0.660^{* * *}$ & $0.698^{* * *}$ & $0.701^{* * *}$ \\
\hline & 0.057 & 0.057 & 0.058 & 0.057 & 0.058 & 0.074 & 0.074 \\
\hline \multicolumn{8}{|l|}{ Bank characteristics } \\
\hline \multirow[t]{2}{*}{ IPO bank's Carter-Manaster rank } & $-0.195^{* * *}$ & $-0.191^{* * *}$ & $-0.195^{* * *}$ & $-0.190^{* * * *}$ & $-0.193^{* * *}$ & $-0.144^{* * *}$ & $-0.142^{* * *}$ \\
\hline & 0.032 & 0.032 & 0.032 & 0.032 & 0.033 & 0.051 & 0.051 \\
\hline \multirow[t]{2}{*}{$=1$ if IPO bank covers stock } & $-0.477^{* * *}$ & $-0.474^{* * *}$ & $-0.472^{* * * *}$ & $-0.479^{* * * *}$ & $-0.472^{* * *}$ & $-0.530^{* * *}$ & $-0.532^{* * *}$ \\
\hline & 0.109 & 0.109 & 0.109 & 0.109 & 0.110 & 0.159 & 0.159 \\
\hline \multirow[t]{2}{*}{$=1$ if IPO bank's analyst is all-star } & -0.167 & -0.174 & -0.184 & -0.171 & -0.183 & -0.123 & -0.124 \\
\hline & 0.119 & 0.119 & 0.120 & 0.119 & 0.120 & 0.150 & 0.150 \\
\hline \multicolumn{8}{|l|}{ Prospect theory variables } \\
\hline \multirow[t]{2}{*}{$=1$ if CEO was 'satisfied' with the IPO } & & $-0.216^{* *}$ & & & & & \\
\hline & & 0.095 & & & & & \\
\hline \multirow[t]{2}{*}{ CEO's log net perceived wealth gain } & & & $-0.009^{* *}$ & & & & \\
\hline & & & 0.004 & & & & \\
\hline \multirow[t]{2}{*}{$=1$ if insiders were 'satisfied' with IPO } & & & & $-0.239^{* *}$ & & & \\
\hline & & & & 0.097 & & & \\
\hline \multirow[t]{2}{*}{ insiders' log net perceived wealth gain } & & & & & $-0.010^{* * *}$ & & \\
\hline & & & & & 0.003 & & \\
\hline \multirow[t]{2}{*}{$=1$ if VCs were 'satisfied' with the IPO } & & & & & & -0.210 & \\
\hline & & & & & & 0.134 & \\
\hline \multirow[t]{2}{*}{ VCs' log net perceived wealth gain } & & & & & & & -0.006 \\
\hline & & & & & & & 0.004 \\
\hline Pseudo $R^{2}$ & $23.5 \%$ & $23.8 \%$ & $23.9 \%$ & $23.9 \%$ & $24.1 \%$ & $23.2 \%$ & $23.3 \%$ \\
\hline Wald $\chi^{2}$ test (all coeff. $=0$ ) & $284.4^{* * *}$ & $290.2^{* * * *}$ & $291.3^{* * *}$ & $292.6^{* * *}$ & $294.4^{* * *}$ & $184.4^{* * *}$ & $185.8^{* * *}$ \\
\hline Number of observations & 1,203 & 1,203 & 1,197 & 1,203 & 1,197 & 687 & 687 \\
\hline
\end{tabular}




\section{Table V. Controlling for CEO Retention}

We re-estimate the models reported in Table IV controlling for whether or not the same CEO was in charge of the issuing firm at the time of the IPO and the SEO. As before the dependent variable is an indicator variable taking the value 1 if the firm switched underwriter between the IPO and the SEO, and 0 otherwise. All explanatory variables are as defined in Table IV. In column 3, the sample size declines by six observations for which the dollar-valued proxy of issuer satisfaction cannot be computed due to division by zero. Intercepts are not shown. White heteroskedasticity-consistent standard errors are reported in italics. We denote significance at the $1 \%$ and $5 \%$ level by ${ }^{* * *}$ and ${ }^{* *}$, respectively.

\begin{tabular}{|c|c|c|c|c|}
\hline & \multicolumn{4}{|c|}{ Same CEO at IPO and SEO? } \\
\hline & $\begin{array}{l}\text { Yes } \\
\text { (1) }\end{array}$ & $\begin{array}{l}\text { No } \\
\text { (2) }\end{array}$ & $\begin{array}{l}\text { Yes } \\
\text { (3) }\end{array}$ & $\begin{array}{l}\text { No } \\
\text { (4) }\end{array}$ \\
\hline \multicolumn{5}{|l|}{ Firm and offer characteristics } \\
\hline \multirow[t]{2}{*}{$\log$ IPO filing size (\$m) } & -0.041 & 0.039 & -0.010 & 0.046 \\
\hline & 0.065 & 0.140 & 0.065 & 0.137 \\
\hline \multirow[t]{2}{*}{$\ln (1+$ age at IPO $)$} & -0.049 & -0.064 & -0.047 & -0.060 \\
\hline & 0.055 & 0.139 & 0.056 & 0.138 \\
\hline \multirow[t]{2}{*}{$=1$ if $\mathrm{EPS}>0$} & $-0.241^{* *}$ & $-0.544^{* * *}$ & $-0.224^{* *}$ & $-0.552^{* *}$ \\
\hline & 0.100 & 0.251 & 0.101 & 0.252 \\
\hline \multirow[t]{2}{*}{$\ln (1+$ initial IPO return $)$} & -0.149 & -1.298 & -0.054 & -1.463 \\
\hline & 0.223 & 0.919 & 0.231 & 0.969 \\
\hline \multirow[t]{2}{*}{$\ln ($ days from IPO to SEO) } & $0.697^{* * * *}$ & $0.254^{* * *}$ & $0.711^{* * *}$ & $0.247^{* * *}$ \\
\hline & 0.064 & 0.179 & 0.065 & 0.179 \\
\hline \multicolumn{5}{|l|}{ Bank characteristics } \\
\hline \multirow[t]{2}{*}{ IPO bank's Carter-Manaster rank } & $-0.203^{* * *}$ & -0.118 & $-0.208^{* * *}$ & -0.125 \\
\hline & 0.034 & 0.079 & 0.034 & 0.078 \\
\hline \multirow[t]{2}{*}{$=1$ if IPO bank covers stock } & $-0.439^{* * *}$ & $-0.646^{* *}$ & $-0.435^{* * *}$ & $-0.649^{* *}$ \\
\hline & 0.120 & 0.280 & 0.121 & 0.279 \\
\hline \multirow[t]{2}{*}{$=1$ if IPO bank's analyst is all-star } & -0.169 & 0.018 & -0.181 & 0.033 \\
\hline & 0.127 & 0.403 & 0.128 & 0.403 \\
\hline \multicolumn{5}{|l|}{ Prospect theory variables } \\
\hline \multirow[t]{2}{*}{$=1$ if CEO was 'satisfied' with the IPO } & $-0.235^{* *}$ & -0.069 & & \\
\hline & 0.101 & 0.285 & & \\
\hline \multirow[t]{2}{*}{ CEO's log net perceived wealth gain } & & & $-0.010^{* * *}$ & 0.002 \\
\hline & & & 0.004 & 0.012 \\
\hline Pseudo $R^{2}$ & $24.0 \%$ & $16.3 \%$ & $24.2 \%$ & $16.3 \%$ \\
\hline Wald $\chi^{2}$ test (all coeff. $=0$ ) & $253.1^{* * *}$ & $29.1^{* * *}$ & $254.9^{* * *}$ & $29.0^{* * *}$ \\
\hline Number of observations & 1,082 & 121 & 1,076 & 121 \\
\hline
\end{tabular}




\section{Table VI. Controlling for CEO Background}

We re-estimate the models reported in Table $\mathrm{V}$ controlling for CEO background. We define a CEO as 'experienced' if he or she was CEO of another firm prior to joining the sample firm. We also condition on the CEO's education. The dependent variable is an indicator variable taking the value 1 if the firm switched underwriter between the IPO and the SEO, and 0 otherwise. Where we use the dollar-valued proxy of issuer satisfaction, the sample size declines by six observations. Intercepts are not shown. White heteroskedasticity-consistent standard errors are reported in italics. We denote significance at the $1 \%, 5 \%$, and $10 \%$ level by $^{* * *},{ }^{* *}$, and ${ }^{*}$, respectively.

\begin{tabular}{|c|c|c|c|c|c|c|c|c|}
\hline & \multicolumn{4}{|c|}{ Experienced CEO? } & \multicolumn{4}{|c|}{ CEO has postgraduate degree? } \\
\hline & Yes & No & Yes & No & Yes & $\begin{array}{l}\text { No } \\
(6)\end{array}$ & Yes & No \\
\hline \multicolumn{9}{|l|}{ Firm and offer characteristics } \\
\hline \multirow[t]{2}{*}{$\log$ IPO filing size (\$m) } & 0.053 & -0.070 & 0.065 & -0.033 & -0.089 & 0.010 & -0.046 & 0.041 \\
\hline & 0.134 & 0.074 & 0.135 & 0.075 & 0.110 & 0.081 & 0.110 & 0.082 \\
\hline \multirow[t]{2}{*}{$\ln (1+$ age at IPO $)$} & 0.003 & -0.069 & 0.007 & -0.067 & -0.072 & -0.036 & -0.072 & -0.032 \\
\hline & 0.105 & 0.065 & 0.106 & 0.066 & 0.128 & 0.061 & 0.128 & 0.062 \\
\hline \multirow[t]{2}{*}{$=1$ if $\mathrm{EPS}>0$} & $-0.480^{* *}$ & -0.174 & $-0.467^{* *}$ & -0.158 & -0.108 & $-0.274^{* *}$ & -0.088 & $-0.256^{* *}$ \\
\hline & 0.212 & 0.113 & 0.213 & 0.114 & 0.169 & 0.129 & 0.170 & 0.130 \\
\hline \multirow[t]{2}{*}{$\ln (1+$ initial IPO return $)$} & -0.614 & -0.033 & -0.451 & 0.048 & -0.229 & -0.120 & -0.138 & -0.021 \\
\hline & 0.520 & 0.243 & 0.529 & 0.252 & 0.369 & 0.286 & 0.383 & 0.293 \\
\hline \multirow[t]{2}{*}{$\ln$ (days from IPO to SEO) } & $0.591^{* * * *}$ & $0.725^{* * *}$ & $0.605^{* * *}$ & $0.739^{* * * *}$ & $0.839^{* * *}$ & $0.633^{* * *}$ & $0.858^{* * *}$ & $0.645^{* * *}$ \\
\hline & 0.136 & 0.073 & 0.139 & 0.073 & 0.112 & 0.079 & 0.113 & 0.080 \\
\hline \multicolumn{9}{|l|}{ Bank characteristics } \\
\hline \multirow[t]{2}{*}{ IPO bank's Carter-Manaster rank } & $-0.246^{* * *}$ & $-0.186^{* * *}$ & $-0.248^{* * *}$ & $-0.193^{* * *}$ & $-0.118^{* *}$ & $-0.256^{* * *}$ & $-0.121^{* *}$ & $-0.263^{* * *}$ \\
\hline & 0.077 & 0.038 & 0.077 & 0.038 & 0.054 & 0.043 & 0.054 & 0.043 \\
\hline \multirow[t]{2}{*}{$=1$ if IPO bank covers stock } & $-0.535^{* *}$ & $-0.428^{* * *}$ & $-0.523^{* *}$ & $-0.425^{* * *}$ & $-0.610^{* * *}$ & $-0.372^{* * *}$ & $-0.616^{* * *}$ & $-0.362^{* *}$ \\
\hline & 0.258 & 0.136 & 0.259 & 0.137 & 0.224 & 0.143 & 0.226 & 0.144 \\
\hline \multirow{2}{*}{$=1$ if IPO bank's analyst is all-star } & -0.158 & -0.177 & -0.187 & -0.185 & -0.093 & -0.188 & -0.091 & -0.207 \\
\hline & 0.250 & 0.146 & 0.250 & 0.146 & 0.238 & 0.151 & 0.239 & 0.153 \\
\hline \multicolumn{9}{|l|}{ Prospect theory variables } \\
\hline \multirow[t]{2}{*}{$=1$ if CEO was 'satisfied' with the IPO } & 0.002 & $-0.284^{* *}$ & & & -0.225 & $-0.247^{* *}$ & & \\
\hline & 0.219 & 0.114 & & & 0.185 & 0.122 & & \\
\hline \multirow[t]{2}{*}{ CEO's log net perceived wealth gain } & & & -0.004 & $-0.012^{* * *}$ & & & -0.010 & $-0.011^{* *}$ \\
\hline & & & 0.009 & 0.004 & & & 0.007 & 0.005 \\
\hline Pseudo $R^{2}$ & $25.4 \%$ & $23.9 \%$ & $25.6 \%$ & $24.0 \%$ & $27.8 \%$ & $22.7 \%$ & $28.0 \%$ & $22.9 \%$ \\
\hline Wald $\chi^{2}$ test (all coeff. $=0$ ) & $60.3^{* * *}$ & $194.4^{* * *}$ & $60.6^{* * *}$ & $195.9^{* * *}$ & $105.0^{* * *}$ & $167.0^{* * * *}$ & $106.7^{* * *}$ & $167.4^{* * *}$ \\
\hline Number of observations & 250 & 832 & 249 & 827 & 350 & 732 & 348 & 728 \\
\hline
\end{tabular}


Table VII. Assessing the Plausibility of the Behavioral Interpretation

Columns 1 and 2 investigate whether the bursting of the 'dot-com bubble' changed the effect of satisfaction with the IPO outcome on SEO underwriter choice. We re-estimate the models reported in Table IV, interacting the behavioral proxies with a dummy variable identifying firms that went public during the 'bubble' period (1999Q1-2000Q2) and completed their SEO after the 'bubble' burst in the second quarter of 2000. In columns 3 and 4, we investigate whether the behavioral proxies merely capture the effect of positive revisions in IPO proceeds, which issuing firms may view as a signal of the underwriter's skill. Proceeds revisions are defined as the percentage difference between actual proceeds (ignoring the over-allotment option where exercised) and intended proceeds as filed in the registration statement. All other explanatory variables are as defined in Table IV. In columns 2 and 4, the sample size declines by six observations for which the dollar-valued proxy of issuer satisfaction cannot be computed due to division by zero. Intercepts are not shown. White heteroskedasticity-consistent standard errors are reported in italics. We denote significance at the $1 \%, 5 \%$, and $10 \%$ level by ${ }^{* * *},{ }^{* *}$, and ${ }^{*}$, respectively.

\begin{tabular}{|c|c|c|c|c|c|}
\hline & \multirow[t]{2}{*}{ Dependent variable: } & \multicolumn{4}{|c|}{ indicator $=1$ if firm switches underwriter } \\
\hline & & $(1)$ & $(2)$ & (3) & $(4)$ \\
\hline \multicolumn{6}{|l|}{ Firm and offer characteristics } \\
\hline \multirow[t]{2}{*}{ log IPO filing size $(\$ \mathrm{~m})$} & & -0.045 & -0.002 & -0.017 & 0.004 \\
\hline & & 0.060 & 0.058 & 0.059 & 0.059 \\
\hline \multirow[t]{2}{*}{$\ln (1+$ age at IPO $)$} & & -0.056 & -0.056 & -0.058 & -0.057 \\
\hline & & 0.051 & 0.051 & 0.051 & 0.051 \\
\hline \multirow[t]{2}{*}{$=1$ if $\mathrm{EPS}>0$} & & $-0.259^{* * *}$ & $-0.254^{* * *}$ & $-0.258^{* * *}$ & $-0.247^{* * *}$ \\
\hline & & 0.092 & 0.093 & 0.093 & 0.093 \\
\hline \multirow[t]{2}{*}{$\ln (1+$ initial IPO return $)$} & & -0.351 & -0.277 & -0.160 & -0.095 \\
\hline & & 0.235 & 0.242 & 0.230 & 0.232 \\
\hline \multirow[t]{2}{*}{$\ln$ (days from IPO to SEO) } & & $0.629^{* * *}$ & $0.645^{* * *}$ & $0.648^{* * *}$ & $0.659^{* * *}$ \\
\hline & & 0.058 & 0.058 & 0.057 & 0.058 \\
\hline \multicolumn{6}{|l|}{ Bank characteristics } \\
\hline \multirow[t]{2}{*}{ IPO bank's Carter-Manaster rank } & & $-0.186^{* * *}$ & $-0.191^{* * *}$ & $-0.189^{* * *}$ & $-0.193^{* * * *}$ \\
\hline & & 0.032 & 0.032 & 0.033 & 0.033 \\
\hline \multirow[t]{2}{*}{$=1$ if IPO bank covers stock } & & $-0.488^{* * *}$ & $-0.477^{* * *}$ & $-0.481^{* * *}$ & $-0.473^{* * *}$ \\
\hline & & 0.109 & 0.109 & 0.110 & 0.110 \\
\hline \multirow[t]{2}{*}{$=1$ if IPO bank's analyst is all-star } & & -0.177 & -0.191 & -0.168 & -0.181 \\
\hline & & 0.119 & 0.120 & 0.119 & 0.120 \\
\hline \multicolumn{6}{|l|}{ Prospect theory variables } \\
\hline \multirow[t]{2}{*}{$=1$ if CEO was 'satisfied' with the IPO } & & $-0.245^{* *}$ & & $-0.178^{*}$ & \\
\hline & & 0.096 & & 0.109 & \\
\hline \multirow[t]{2}{*}{$\times$ post-bubble SEO } & & $0.381^{* *}$ & & & \\
\hline & & 0.194 & & & \\
\hline \multirow[t]{2}{*}{ CEO's log net perceived wealth gain } & & & $-0.010^{* * *}$ & & $-0.009^{* *}$ \\
\hline & & & 0.004 & & 0.004 \\
\hline \multirow[t]{2}{*}{$\times$ post-bubble SEO } & & & $0.018^{*}$ & & \\
\hline & & & 0.010 & & \\
\hline \multicolumn{6}{|l|}{ Proceeds revisions } \\
\hline \multirow[t]{2}{*}{ change in offer size relative to first filing } & & & & -0.207 & -0.111 \\
\hline & & & & 0.190 & 0.194 \\
\hline Pseudo $R^{2}$ & & $24.1 \%$ & $24.1 \%$ & $24.0 \%$ & $24.1 \%$ \\
\hline Wald $\chi^{2}$ test (all coeff. $=0$ ) & & $291.0^{* * *}$ & $292.7^{* * *}$ & $300.6^{* * *}$ & $300.0^{* * *}$ \\
\hline Number of observations & & 1,203 & 1,197 & 1,203 & 1,197 \\
\hline
\end{tabular}




\section{Table VIII. Conditional Logit Models of the SEO Underwriter Choice}

The conditional logits model issuing companies as choosing their SEO lead-manager from among a set of two banks: the IPO underwriter and a 'new bank'. The new bank is the one actually chosen if a switch has taken place. If the firm retains its IPO underwriter, we assume the alternative new bank has the same characteristics as either the IPO underwriter (Scenario 1), the average bank (Scenario 2), or the best bank (Scenario 3). The parameters for Scenario 2 are a Carter-Manaster rank of 7.25, no research coverage, and the absence of an all-star analyst. For Scenario 3, they are a rank of 9.1 (the highest possible), coverage, and the presence of an all-star analyst. We relate the probability of observing these choices to two classes of variables: the issuer's attributes and the attributes of the choice (i.e. the banks' characteristics). Note that while issuer attributes vary across issuers, they are constant for each issuer whichever bank is chosen. Conditional logit models estimate the effect of issuer attributes by interacting such variables with a dummy for one of the choices. Without loss of generality, we interact them with a dummy 'newbank' that equals 1 for the new bank. The coefficients are interpreted as estimates of the effect of issuer attributes on the likelihood that the issuer switches banks. In columns 2, 4, and 6, the sample size declines by six observations for which the dollar-valued proxy of issuer satisfaction cannot be computed due to division by zero. White heteroskedasticity-consistent standard errors are reported in italics. We denote significance at the 1\%, 5\%, and 10\% level by *****, and ${ }^{*}$, respectively.

\begin{tabular}{|c|c|c|c|c|c|c|}
\hline & \multicolumn{2}{|c|}{ Scenario 1} & \multicolumn{2}{|c|}{ Scenario 2} & \multicolumn{2}{|c|}{ Scenario 3} \\
\hline & $(1)$ & $(2)$ & $(3)$ & (4) & $(5)$ & $(6)$ \\
\hline \multicolumn{7}{|l|}{ Attributes of the issuer } \\
\hline \multirow[t]{2}{*}{$\log$ IPO filing size $(\$ \mathrm{~m}) \times$ newbank } & $-0.744^{* * *}$ & $-0.719^{* * *}$ & $-0.300^{* * *}$ & $-0.288^{* * *}$ & $-1.032^{* * *}$ & $-1.031^{* * *}$ \\
\hline & 0.079 & 0.080 & 0.097 & 0.097 & 0.111 & 0.112 \\
\hline \multirow[t]{2}{*}{$\ln (1+$ age at IPO $) \times$ newbank } & $-0.170^{* *}$ & $-0.170^{* *}$ & $-0.177^{*}$ & $-0.179^{*}$ & 0.032 & 0.025 \\
\hline & 0.086 & 0.086 & 0.105 & 0.105 & 0.112 & 0.112 \\
\hline \multirow[t]{2}{*}{$($ dummy $=1$ if EPS $>0) \times$ newbank } & $-0.706^{* * *}$ & $-0.723^{* * *}$ & $-0.839^{* * *}$ & $-0.843^{* * *}$ & $-0.464^{* *}$ & $-0.480^{* *}$ \\
\hline & 0.155 & 0.155 & 0.188 & 0.187 & 0.214 & 0.214 \\
\hline \multirow[t]{2}{*}{$\ln (1+$ initial IPO return $) \times$ newbank } & $-1.666^{* * *}$ & $-1.979^{* * *}$ & -0.564 & -0.707 & $-1.877^{* * *}$ & $-1.917^{* * *}$ \\
\hline & 0.386 & 0.401 & 0.440 & 0.452 & 0.472 & 0.482 \\
\hline \multirow[t]{2}{*}{$\ln ($ days from IPO to SEO $) \times$ newbank } & $0.571^{* * *}$ & $0.518^{* * *}$ & $0.606^{* * *}$ & $0.563^{* * *}$ & $0.893^{* * *}$ & $0.859^{* * *}$ \\
\hline & 0.054 & 0.052 & 0.066 & 0.064 & 0.079 & 0.077 \\
\hline \multicolumn{7}{|l|}{ Attributes of the choice } \\
\hline \multirow[t]{2}{*}{ bank's Carter-Manaster rank } & $0.189^{* * *}$ & $0.189^{* * *}$ & $0.396^{* * *}$ & $0.394^{* * *}$ & -0.085 & -0.088 \\
\hline & 0.045 & 0.045 & 0.052 & 0.052 & 0.058 & 0.058 \\
\hline \multirow[t]{2}{*}{$=1$ if bank covers stock } & $-1.409^{* * *}$ & $-1.392^{* * *}$ & $2.650^{* * *}$ & $2.653^{* * *}$ & $-0.921^{* * *}$ & $-0.907^{* * *}$ \\
\hline & 0.183 & 0.183 & 0.182 & 0.182 & 0.221 & 0.220 \\
\hline \multirow[t]{2}{*}{$=1$ if bank's analyst is all-star } & 0.148 & 0.145 & 0.321 & 0.308 & $-3.806^{* * *}$ & $-3.805^{* * *}$ \\
\hline & 0.283 & 0.284 & 0.243 & 0.243 & 0.240 & 0.239 \\
\hline \multicolumn{7}{|l|}{ Prospect theory variables } \\
\hline \multirow[t]{2}{*}{$(=1$ if CEO was 'satisfied' with IPO $) \times$ newbank } & $-0.620^{* * *}$ & & $-0.546^{* * *}$ & & $-0.506^{* *}$ & \\
\hline & 0.159 & & 0.192 & & 0.226 & \\
\hline \multirow[t]{2}{*}{ (CEO's log net perceived wealth gain $) \times$ newbank } & & $-0.013^{* *}$ & & $-0.015^{* *}$ & & $-0.015^{* *}$ \\
\hline & & 0.006 & & 0.007 & & 0.007 \\
\hline Pseudo $R^{2}$ & $26.4 \%$ & $25.6 \%$ & $46.0 \%$ & $45.6 \%$ & $57.7 \%$ & $57.5 \%$ \\
\hline Wald $\chi^{2}$ test (all coeff. $=0$ ) & $440.1^{* * *}$ & $425.0^{* * *}$ & $766.5^{* * *}$ & $755.8^{* * *}$ & $962.1^{* * *}$ & $954.2^{* * *}$ \\
\hline Number of firms & 1,203 & 1,197 & 1,203 & 1,197 & 1,203 & 1,197 \\
\hline
\end{tabular}




\section{Table IX. Determinants of SEO Spreads}

We estimate ordinary least-squares models with the underwriter spread charged for the SEO as the dependent variable. SEO spreads are measured in percent. Following the literature, we control for the amount raised at the SEO (in log real dollars), firm quality (measured using the volatility of daily stock returns estimated over the 230 trading days ending 20 days before the SEO, the EPS dummy introduced in Table IV, and the firm's real log market capitalization as of the month-end prior to the SEO date), and aggregate primary market activity (measured as the log real amount raised in all IPOs and SEOs in the three calendar months preceding the SEO). The sample size decreases by the 24 firms for which prospectuses fail to report the spread paid to the SEO underwriter. In columns 2 through 4, the sample size declines by six observations for which the dollar-valued proxy of issuer satisfaction cannot be computed due to division by zero. White heteroskedasticity-consistent standard errors are reported in italics. We denote significance at the $1 \%$ and $5 \%$ level by ${ }^{* * *}$ and ${ }^{* * *}$, respectively.

\begin{tabular}{|c|c|c|c|c|}
\hline & \multicolumn{2}{|c|}{ Whole sample } & \multicolumn{2}{|c|}{ Switching underwriter? } \\
\hline & (1) & $(2)$ & $\begin{array}{l}\text { No } \\
\text { (3) }\end{array}$ & $\begin{array}{l}\text { Yes } \\
(4)\end{array}$ \\
\hline \multicolumn{5}{|l|}{ Issue size } \\
\hline \multirow[t]{2}{*}{ log real SEO proceeds } & $-0.208^{* * *}$ & $-0.208^{* * *}$ & $-0.230^{* * *}$ & $-0.174^{* *}$ \\
\hline & 0.037 & 0.036 & 0.037 & 0.080 \\
\hline \multicolumn{5}{|l|}{ Firm quality } \\
\hline \multirow[t]{2}{*}{ daily stock return volatility } & $0.006^{* * *}$ & $0.006^{* * * *}$ & $0.004^{* * * *}$ & $0.008^{* * *}$ \\
\hline & 0.001 & 0.001 & 0.001 & 0.002 \\
\hline \multirow[t]{2}{*}{$=1$ if $\mathrm{EPS}>0$} & $-0.205^{* * *}$ & $-0.196^{* * *}$ & $-0.185^{* * *}$ & $-0.173^{* *}$ \\
\hline & 0.042 & 0.041 & 0.046 & 0.075 \\
\hline \multirow[t]{2}{*}{ log real market capitalization } & $-0.432^{* * *}$ & $-0.434^{* * *}$ & $-0.363^{* * *}$ & $-0.523^{* * *}$ \\
\hline & 0.034 & 0.034 & 0.040 & 0.069 \\
\hline \multicolumn{5}{|l|}{ Primary market activity } \\
\hline \multirow[t]{2}{*}{ log aggregate proceeds in prior three months } & $0.158^{* * *}$ & $0.162^{* * *}$ & $0.131^{* * *}$ & $0.221^{* *}$ \\
\hline & 0.049 & 0.049 & 0.050 & 0.113 \\
\hline \multicolumn{5}{|l|}{ Prospect theory variables } \\
\hline \multirow{2}{*}{$=1$ if CEO was 'satisfied' with the IPO } & $0.117^{* * *}$ & & & \\
\hline & 0.038 & & & \\
\hline \multirow[t]{2}{*}{ CEO's log net perceived wealth gain } & & $-0.018^{* * *}$ & $-0.031^{* * *}$ & -0.002 \\
\hline & & 0.006 & 0.006 & 0.011 \\
\hline \multirow{2}{*}{$\begin{array}{l}\text { CEO's log net perceived wealth gain * (dummy }=1 \text { if } \\
\text { CEO was 'satisfied') }\end{array}$} & & $0.038^{* * * *}$ & $0.057^{* * *}$ & 0.015 \\
\hline & & 0.011 & 0.012 & 0.022 \\
\hline \multirow[t]{2}{*}{ constant } & $6.846^{* * *}$ & $6.630^{* * *}$ & $6.510^{* * *}$ & $6.494^{* * *}$ \\
\hline & 0.491 & 0.492 & 0.492 & 1.101 \\
\hline Adjusted $R^{2}$ & $53.7 \%$ & $54.4 \%$ & $55.4 \%$ & $50.1 \%$ \\
\hline Wald $F$-test (all coeff. $=0$ ) & $119.8^{* * *}$ & $103.7^{* * *}$ & $65.9^{* * *}$ & $35.3^{* * * *}$ \\
\hline Number of observations & 1,179 & 1,173 & 765 & 408 \\
\hline
\end{tabular}

